\title{
Review
}

\section{Mitigating Batrachochytrium salamandrivorans in Europe}

\author{
Valarie Thomas ${ }^{1, * * *}$, Yu Wang ${ }^{1, * *}$, Pascale Van Rooij ${ }^{1}$, Elin Verbrugghe ${ }^{1}$, Vojtech Baláž ${ }^{2}$, \\ Jaime Bosch ${ }^{3}$, Andrew A. Cunningham ${ }^{4}$, Matthew C. Fisher ${ }^{5}$, Trenton W.J. Garner ${ }^{4}$, \\ Maarten J. Gilbert ${ }^{6,7}$, Elena Grasselli ${ }^{8}$, Thierry Kinet ${ }^{9}$, Arnaud Laudelout ${ }^{9}$, Stefan Lötters ${ }^{10}$, \\ Adeline Loyau ${ }^{11,12}$, Claude Miaud ${ }^{13}$, Sebastiano Salvidio ${ }^{8}$, Dirk S. Schmeller ${ }^{11}$, \\ Benedikt R. Schmidt ${ }^{14,15}$, Annemarieke Spitzen-van der Sluijs ${ }^{6}$, Sebastian Steinfartz ${ }^{16}$, \\ Michael Veith ${ }^{10}$, Miguel Vences ${ }^{17}$, Norman Wagner ${ }^{10}$, Stefano Canessa ${ }^{1}$, An Martel ${ }^{1}$, \\ Frank Pasmans ${ }^{1}$
}

\begin{abstract}
The infectious chytrid fungus Batrachochytrium salamandrivorans (Bsal) has been responsible for severe population declines of salamander populations in Europe. Serious population declines and loss of urodelan diversity may occur if appropriate action is not taken to mitigate against the further spread and impact of Bsal. We provide an overview of several potential mitigation methods, and describe their possible advantages and limitations. We conclude that long-term, context-dependent, multi-faceted approaches are needed to successfully mitigate adverse effects of Bsal, and that these approaches should be initiated pre-arrival of the pathogen. The establishment of ex situ assurance colonies, or management units, for species threatened with extinction, should be considered as soon as possible. While ex situ conservation and preventive measures aimed at improving biosecurity by limiting amphibian trade may be implemented quickly, major challenges that lie ahead are in designing in situ disease containment and mitigation post-arrival and in increasing public awareness.
\end{abstract}

Keywords: amphibians, Batrachochytrium salamandrivorans, biosecurity, chytrid fungus, chytridiomycosis, conservation, emerging diseases, mitigation, salamanders, trade.

1 - Wildlife Health Ghent, Department of Pathology, Bacteriology and Avian Diseases, Faculty of Veterinary Medicine, Ghent University, Salisburylaan 133, Merelbeke, Belgium

2 - Department of Ecology and Diseases of Game, Fish and Bees, University of Veterinary and Pharmaceutical Sciences Brno, Palackého tř. 1946/1, 61242 Brno, Czech Republic

3 - Museo Nacional de Ciencias Naturales-CSIC, 28006 Madrid, Spain

4 - Institute of Zoology, Zoological Society of London, Regent's Park, London NW1 4RY, UK

5 - MRC Centre for Global Infectious Disease Analysis, School of Public Health, Imperial College London, UK

6 - Reptile, Amphibian \& Fish Conservation Netherlands, PO Box 1413, 6501 BK Nijmegen, The Netherlands

7 - Department of Infectious Diseases and Immunology, Faculty of Veterinary Medicine, Utrecht University, The Netherlands

8 - DISTAV - Università di Genova, Italy
9 - Natagora, Département Etudes, 1 Traverse des Muses, B-5000 Namur, Belgium

10 - Department of Biogeography, Trier University, Universitätsring 15, 54296 Trier, Germany

11 - EcoLab, Université de Toulouse, UPS, INPT, CNRS, Toulouse, France

12 - Department of Limnology of Stratified Lakes, Institute of Freshwater Ecology and Inland Fisheries, Neuglobsow, Germany

13 - PSL, UMR 5175 CEFE, EPHE, Biogeography and vertebrate Ecology, Montpellier, France

14 - Department of Evolutionary Biology and Environmental Studies, University of Zurich, Winterthurerstrasse 190, 8057 Zurich, Switzerland

15 - Info Fauna Karch, UniMail, Bâtiment G, Bellevaux 51, 2000 Neuchâtel, Switzerland

16 - University of Leipzig, Institute of Biology, Molecular Evolution and Systematics of Animals, Talstrasse 33, 04103 Leipzig, Germany 


\section{Introduction}

Infection of an amphibian host with the chytrid fungi Batrachochytrium dendrobatidis $(B d)$ or B. salamandrivorans (Bsal), may cause clinical chytridiomycosis, an emerging infectious disease (EID) (Berger et al., 1998; Martel et al., 2013). $B d$ was first identified in the 1990s as the prevailing cause of worldwide enigmatic declines and local extirpations of amphibian populations (Berger et al., 1998; Longcore et al., 1999). In 2013, Bsal was described following a population collapse of European fire salamanders (Salamandra salamandra) in the Netherlands from 2010 onwards, of which less than $0.1 \%$ of the original population remained in 2016 (Spitzen-van der Sluijs et al., 2013, 2016). In-depth study of a similar outbreak in Belgium in 2014 demonstrated how the interplay between host, pathogen and environment is predicted to result in the extirpation of the affected fire salamander population (Stegen et al., 2017).

Both $B d$ and Bsal are highly contagious and are transmitted effectively by direct contact with pathogen shedding hosts or indirectly by contact with contaminated water or substrate (Bosch and Martinez-Solano, 2006; Garmyn et al., 2012; Kolby et al., 2014; Martel et al., 2014; Courtois et al., 2017; Stegen et al., 2017). Pathogen transmission for both amphibian chytrid fungi is via aquatic, motile zoospores which infect the epidermal cells of amphibian skin. Further, Bsal produces an infectious, non-motile, encysted spore that manifests increased environmental resilience (Stegen et al., 2017). Although not completely understood, the release of proteases by $B d$ zoospores and the growth of intracellular $B d$ and $B s a l$ zoosporangia cause disruption of normal skin functioning which is vital to amphibian survival

17 - Technische Universität Braunschweig, Zoological Institute, Mendelssohnstr. 4, 38106 Braunschweig, Germany

*Corresponding author;

e-mail: Valarie.Thomas@ugent.be

${ }^{* *}$ These authors contributed equally to this work
(Berger, Speare and Kent, 1999; Voyles et al., 2009; Brutyn et al., 2012; Martel et al., 2013; Van Rooij et al., 2015; Farrer et al., 2017).

Although $B d$ and Bsal belong to the same genus, they diverged an estimated 50 million years ago (Martel et al., 2014). Bsal is considered endemic in East Asia where it is widespread, at least in Vietnam, Japan and China, in species of the family Salamandridae (Laking et al., 2017; Yuan et al., 2018). Both species have an arsenal of virulence factors, which include a greatly expanded metalloprotease gene-family in Bsal (Farrer et al., 2017). Optimal growth temperatures for $B d$ range between $17^{\circ} \mathrm{C}$ and $25^{\circ} \mathrm{C}$ compared to $10-15^{\circ} \mathrm{C}$ for the Bsal type strain. Temperatures above $25^{\circ} \mathrm{C}$ and $30^{\circ} \mathrm{C}$ are lethal for $B s a l$ and $B d$ respectively (Piotrowski et al., 2004; Martel et al., 2013; Blooi et al., 2015a). However, natural infections with Bsal were shown to occur in Asiatic newts of the genus Tylototriton at water temperatures up to $26^{\circ} \mathrm{C}$, suggesting variation in thermal tolerance between $\mathrm{Bsal}$ isolates and, possibly, lineages (Laking et al., 2017; Beukema et al., 2018).

$B d$ can infect the skin of, and cause lethal disease in, a large range of anurans, urodeles and caecilians, although population declines have been observed mainly in anurans (Skerrat et al., 2007). In comparison, disease caused by Bsal seems to be limited to urodeles (Martel et al., 2014), even though some anurans can be infected by this fungus (Nguyen et al., 2017; Stegen et al., 2017). The currently observed niche breadth of Bsal in Europe appears to be only partially filled, indicating a high potential of further spread of Bsal (Beukema et al., 2018). The international trade of Asian salamanders and newts is suspected to be the primary route for the intercontinental spread of Bsal (Martel et al., 2014; Nguyen et al., 2017; Yuan et al., 2018). However, in captive collections outside Asia, infection can spread to other species, which in turn, can spread Bsal when traded (Fitzpatrick et al., 2018; Sabino-Pinto et al., 2018b). Eliminating this captive reservoir of $B s a b_{1}$ should be a key: $01 \mathrm{Am}$ 
aim in order to curtail further spillover events into natural populations of naïve amphibians.

Given the high susceptibility of salamanders to Bsal (Martel et al., 2014), and the infectiousness, pathogenicity and host range of the pathogen in Europe (Spitzen-van der Sluijs et al., 2016; Stegen et al., 2017; Dalbeck et al., 2018), Bsal poses an unprecedented threat to non-Asian salamander species (Beukema et al., 2018). Also, the prevalence of Bsal can be low in Asian reservoir species in captivity (Martel et al., 2014; Fitzpatrick et al., 2018) rendering detection difficult. Such pathogen reservoirs pose a formidable challenge for effectively preventing the introduction of Bsal, or subsequently managing a disease outbreak (Canessa et al., 2018). The development of effective mitigation strategies and measures, therefore, is crucial to maintaining amphibian biodiversity both globally and locally (Woodhams et al., 2011; Garner et al., 2016). Bsal abatement options have been considered before (Grant et al., 2015) and are continuously under revision by the US $\mathrm{Bsal}$ taskforce. Here, we propose a set of options we deem most feasible and efficient for the European situation given the current state of knowledge.

Two decades of research on the amphibian chytrid fungi have not yielded a single, globally effective measure for controlling $B d$ (Garner et al., 2016). Despite this, knowledge gained from these efforts is informative and has guided the development of our proposed suite of actions that are most likely to be effective in mitigating the effects of Bsal in Europe.

\section{Pre-exposure measures}

Taking actions to prevent the introduction and spread of Bsal into naïve regions is currently considered as the most efficient control method available ("prevention is better than cure"; Langwig et al., 2015; Richgels et al., 2016; Grant et al., 2017; Roy et al., 2017). Within Europe, the potential threat posed by Bsal was first recognised by the standing committee of the
Bern Convention (Convention on the conservation of European Wildlife and Natural Habitats, 1979). In December 2015, the Council of Europe released recommendation No. 176 which aims to reduce the likelihood of Bsal expanding its range throughout Europe. This recommendation states that the signatories develop a number of precautions, including i) imposing trade restrictions on salamanders until risk assessments and prevention/mitigation protocols have been developed, ii) pre-import screening for the pathogen in the live animal trade, iii) setting up and implementing monitoring, surveillance and early-warning systems to detect Bsal incursion into the wild as well as the expansion of its range following its introduction, and iv) requiring biosecurity for field work, breeding sites and captive collections.

\subsection{Trade restrictions and import controls}

Since the international trade of salamanders and newts is suspected to be the principal route for the international spread of Bsal, bans/restrictions on amphibian trade, alongside controls at import pathways, are likely to be the most effective precautionary measures for preventing the introduction of Bsal via amphibian vectors in Bsal-free countries (Fitzpatrick et al., 2018; O'Hanlon et al., 2018). Wildlife trade restrictions, improved quarantine and strengthened biosecurity measures will also reduce the probability of introducing yet unknown pathogens and will thus have an impact beyond Bsal.

Such actions have already been implemented in several countries outside the European Union (EU) for example the United States (US Fish and Wildlife Service, 2016; EFSA, 2017a; Klocke et al., 2017) and Canada (EFSA, 2017a; Canada Gazette Part II, 2017; Wild Animal and Plant Protection Regulation of International and Interprovincial Act, 2017, updated May 12, 2018). The trade restrictions can be found summarised in supplementary table S1.

Within the European continent, import restrictions have been implemented in Switzer-

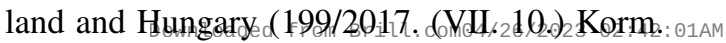


Rendelet, 2017; EFSA, 2018; Stark et al., 2018) and in 2018, the European Commission issued temporary legislation (2018/320) which establishes animal health protection measures for the trade of salamanders within the EU and the importation of salamanders from non-EU territories (EFSA, 2018; Stark et al., 2018). There are omissions that weaken this regulation's relevance (Auliya et al., 2016), for example, the non-inclusion of anurans, which can act as Bsal carriers (Nguyen et al., 2017; Stegen et al., 2017) and not regulating animal traffic between private individuals.

Although policy-making with the aim of curtailing the spread of Bsal has been conducted relatively quickly in the countries mentioned above, coordinated global measures are required to regulate both the formal (e.g. commercial) and informal (e.g. hobbyists, fairs) amphibian trade (Auliya et al., 2016) in order to mitigate the spread of pathogens such as Bsal.

\subsection{Additional control measures}

Import bans of caudates alone may create a false feeling of security. They are unlikely to be $100 \%$ effective and $\mathrm{Bsal}$ is already present in captive amphibians in European regions where no Bsal outbreaks in the wild have been reported yet (Fitzpatrick et al., 2018; Sabino-Pinto et al., 2018b). Within the EU, the trade in captive urodeles has been shown to contribute to the international spread of Bsal (Fitzpatrick et al., 2018). Thorough screening of captive collections for Bsal (e.g. carried out in Germany; Sabino-Pinto et al., 2018b; and France; Marquis et al., 2019) and immediate treatment of these captive collections upon detection, are urgently needed to eliminate this Bsal reservoir, preferably supported by legislation. Based on an estimation of the number of amphibian keepers and number of pet amphibians in Europe, a total initial screening cost of the European states would be well below 1 million Euros as presented in supplementary table $\mathrm{S} 2$. Clean trade, meaning the absence of known pathogens throughout the commercial chain, was promoted as a condition for sustainable exotic pet ownership (Pasmans et al., 2017). The sale of caudates in garden centers and other retail outlets should be discouraged, since this suggests suitability for release in garden ponds, which could promote the release of contaminated animals. Several stakeholders have set up campaigns to raise awareness of Bsal (see supplementary fig. S1).

\subsection{Biosecurity measures}

It is essential to curb anthropogenic spread of Bsal during fieldwork, laboratory research, trade, recreational activities and amphibian husbandry by educating all including the public on appropriate biosecurity measures after use of amphibian habitats (Loyau and Schmeller, 2017). An effective measure to avoid spread of this pathogen during fieldwork is to ensure that proper disinfection protocols are utilised for hands, apparel, footwear, equipment and vehicles used in the field (EFSA, 2017b). Bsal can be killed using most common disinfectants (table 1) (Van Rooij et al., 2017). Individuals involved in amphibian husbandry should ensure that captive urodeles are not housed outdoors and that captive amphibians are not released into the wild. They should also ensure that all waste is properly disinfected and disposed of (EFSA, 2017b).

Virkon S (Pfizer Limited) is used widely, relatively safe and highly efficient, but its use in the field may require derogations from existing legislation. Ethanol (and probably methanol) based commercial disinfectants can also be used effectively. Bleach is also highly effective. Soaking equipment in $10 \%$ sodium chloride for 10 minutes is potentially an effective, nontoxic and cheap alternative and its use is worth exploring further. Unfortunately, the commonly used and relatively cheap disinfectant, hydrogen peroxide, has poor activity against Bsal (Van Rooij et al., 2017). The efficacy of these disinfectants in table 1 against cysts is unknown, however, it is expected to be lower than for spores and spo-

rangia. Downloaded from Brill.com04/26/2023 02:42:01AM via free access 
Table 1. Minimal exposure time for $100 \%$ killing of $\mathrm{Bsal}$ spores and sporangia in water and on fomites at room temperature (Van Rooij et al., 2017).

\begin{tabular}{|c|c|c|}
\hline Disinfectant & Concentration & $\begin{array}{l}\text { Minimal exposure time for } 100 \% \\
\text { killing of Bsal }\end{array}$ \\
\hline Ethanol (EtOH) & $70 \%$ & $30 s$ \\
\hline Disolol $^{\circledR}$ & undiluted & $30 \mathrm{~s}$ \\
\hline Hibiscrub ${ }^{\circledR}$ & $0.25,0.5,0.75 \%$ & $30 \mathrm{~s}$ \\
\hline \multirow[t]{2}{*}{ Chloramine- $T^{\circledR}$} & $0.5 \%$ & 5 minutes \\
\hline & $1 \%$ & 2 minutes \\
\hline Bleach & $4 \%$ & $30 \mathrm{~s}$ \\
\hline \multirow[t]{2}{*}{ Kickstart $^{\circledR}$} & $0.05 \%$ & 5 minutes \\
\hline & $0.1 \%$ & 2 minutes \\
\hline \multirow[t]{2}{*}{ Potassium permanganate $\left(\mathrm{KMnO}_{4}\right)$} & $1 \%$ & 10 minutes \\
\hline & $2 \%$ & 5 minutes \\
\hline \multirow[t]{2}{*}{ Virkon $S^{\circledR}$} & $0.5 \%$ & 5 minutes \\
\hline & $1 \%$ & 2 minutes \\
\hline Dettol medical ${ }^{\circledR}$ & $1: 20$ dilution & 5 minutes \\
\hline Biocidal $^{\circledR}$ & undiluted & $30 \mathrm{~s}$ \\
\hline Safe $4^{\circledR}$ & undiluted & $30 \mathrm{~s}$ \\
\hline \multirow[t]{4}{*}{$\mathrm{F} 10^{\circledR}$} & $1: 100$ dilution & $30 \mathrm{~s}$ \\
\hline & $1: 250$ dilution & $30 \mathrm{~s}$ \\
\hline & 1:500 dilution & $30 \mathrm{~s}$ \\
\hline & $1: 1000$ dilution & $30 \mathrm{~s}$ \\
\hline Sodium chloride $(\mathrm{NaCl})$ & $10 \%$ & 10 minutes \\
\hline
\end{tabular}

Heat treatment can kill all life stages of Bsal but its routine use as a disinfectant requires further study. The fungus tolerates high temperatures poorly: Bsal cultures are killed after incubation for 5 days at $25^{\circ} \mathrm{C}$ (Blooi et al., 2015a). If $B$ sal responds to heat in the same way as its sister species $B d$, then exposing materials to $60^{\circ} \mathrm{C}$ for 5 minutes or $100^{\circ} \mathrm{C}$ for 1 minute should be an efficient disinfection procedure (Johnson et al., 2003). Drying may kill Bsal, however, since it is currently not known to what extent encysted Bsal spores tolerate drying, it is not recommended as the sole disinfection procedure.

In cases of Bsal incursion into the wild, drastic measures, such as closing areas to the public, might be required but such actions might not be compatible with local regulations, as was the case in the Netherlands and Belgium (EFSA, 2017b).

Pre-emergence measures can reduce the likelihood of introducing Bsal into naïve locations at a relatively low cost. Isolated populations of Bsal-threatened species might be considered as disease refugia and be managed by limiting human interaction. However, precautionary measures alone may not be sufficient, particularly without a full understanding of transmission routes for, and potential vectors of, Bsal.

\subsection{Increasing host resistance}

Host resistance against $\mathrm{Bsal}$ is currently poorly understood. However, adhesion to, and invasion of, the salamander skin are key events that appear to determine the outcome of infection (Martel et al., 2014). Provoking a hereditary reduction in the susceptibility of highly susceptible urodelan species may be the only sustainable measure to avert further loss of biodiversity in the long term, given the high probability that Bsal will not be eliminated once it has invaded an ecosystem (Feldmeier et al., 2016; Schmidt et al., 2017; Stegen et al., 2017). If we decide to assist in decreasing host susceptibility, three options may be worth exploring: vaccination, bioaugmentation using pre- or probiotics and selective breeding. Based on their close genetic compositions we tend to expect similar responses from both pathogens $s_{c}$ and the ${ }_{0}$ various: $01 \mathrm{Am}$ 
strains to these pre-exposure mitigation methods. Bsal's genome is $32.6 \mathrm{Mb}$ while Bd's is 23.7 Mb (Farrer et al., 2017). Therefore, though there are commonalities, there are still differences which are reflected in the two pathogens being separate species. For example, any intervention which relies on salamanders mounting an immune response is likely to be less successful against Bsal (Stegen et al., 2017) than other amphibians against $B d$.

\subsubsection{Vaccination. Although there is lim-} ited evidence that the development of a $B d$ vaccine might be possible (Woodhams et al., 2011; McMahon et al., 2014), similar trials with $B s a l$ have not resulted in any protection against a challenge with virulent Bsal (Stegen et al., 2017). There are currently no proofs of concept available for vaccination against Bsal. This is probably because $B$ sal severely suppresses immune response in infected hosts (Farrer et al., 2017), negating the animal's ability to mount an effective response.

Developing a vaccine is likely to be costly and any vaccine would need to be useful in a range of species. In addition, the creation of vaccines for fungal agents has proven to be much more difficult than for viruses or bacteria, as evidenced by the lack of antifungal animal vaccines. For Bsal, there are currently no proofs of concept available. There may also be a need to develop appropriate policy and budget allocations to allow the vaccination of free-living wildlife (Garner et al., 2016). Finally, vaccination which requires application to individual wild salamanders would be logistically highly challenging in situ (Garner et al., 2016; Canessa et al., 2018) especially if booster doses were required.

In spite of such challenges, vaccination would be an appealing option in the event that a Bsal strain (or another chytrid/microorganism) was isolated/designed that establishes self-sustaining populations in amphibian communities, is avirulent, safe for target and non-target species, yet evokes a protective response against virulent $B s a l$ across host species and life stages and for different chytrid genotypes.

\subsubsection{Bioaugmentation. Bioaugmentation is} a method of inoculating beneficial probiotics into or on to the animal host or habitat to reduce host susceptibility by microbial defences (Woodhams et al., 2011). Probiotics have been isolated from soil, water and amphibian skin (Loudon et al., 2014). Bd-induced chytridiomycosis has been mitigated, although with variable success by bioaugmentation in the laboratory and in a field trial (Bletz et al., 2013), and probiotic therapy should be considered as a potential strategy for Bsal mitigation. Knowing any potential risks that probiotics pose to ecosystems and amphibian hosts is important prior to any application to wild populations. The risks of an uncontrolled introduction of probiotics in the wild are manifold, including disruption of nutrient cycling, which could have important cascade effects for the whole ecosystem (Schmeller et al., 2018).

In addition, a suitable probiotic for bioaugmentation should be effective across Bsal genotypes, should result in persistent colonisation of the urodelan skin at densities that facilitate their antifungal activity, should preferably be transmissible to conspecifics (including offspring) and should be safe and espouse qualities which would allow it to be produced in large volumes. In order to understand the bacterial community on amphibian skin and identify the effect of probiotics on Bsal establishment, a much better understanding will be required (Bates et al., 2018), including of the host-pathogen-environment triangle (Schmeller et al., 2018). Recent work by Bletz et al. (2018) and Bates et al. (2018) has shown that Bsal-induced death coincides with significant perturbation of the bacterial community, resulting in increases of opportunistic bacteria that cause septicaemic events (Bletz et al., 2018). Besides, the composition of bacterial communities on urodele skin is highly dependent on their surrounding environment, raising the possibility that laboratory trials with Bsal may be influenced by the mere transition: 01AM 
of the animals to captivity (Bates et al., 2018). Currently, there are no proofs of concept that bacteria or other microbes protect susceptible salamanders against Bsal infection at natural microbial densities. On the contrary, Bletz et al. (2018) suggest that bioaugmentation might be impeded, at least in fire salamanders, as very low numbers of bacteria are maintained on their skin.

Although these bacterial communities on the salamander skin do contain bacterial lineages with pronounced Bsal-inhibiting capacity in vitro, only the repeated and consistent application of very high doses of these lineages were capable of attenuating $\mathrm{Bsal}$ infection (Bletz, et al., 2018).

\subsubsection{Selective breeding. Increasing resis-} tance against Bsal infection either by selective breeding (resembling natural selection by cross breeding the most resistant animals) or by genetic engineering could be an effective strategy in the mid- to long-term to permanently avert the risk of $B s a l$-induced population crashes. Based on their close genetic compositions we tend to expect similar responses from both pathogens to selective breeding. However, while there are commonalities, there are still difference in genetic composition and still a lot of important information on Bsal yet to be elucidated. While some frogs exposed to $B d$ and antifungals demonstrated a reduction in susceptibility (Garner et al., 2016), salamanders previously exposed to Bsal did not demonstrate decreased susceptibility (reduced mortality) (Stegen et al., 2017).

Further, this would require extensive resources for training staff in genetic engineering, infrastructure and genetic management. Selective breeding requires the availability of markers for resistance. Genetic engineering requires the identification of the genetic basis underpinning host resistance (with relevance for the situation in the wild). While gene editing in amphibian eggs is commonplace, genetic engineering in viviparous species of the genus Salaman$d r a$ presents an additional challenge. For $B d$, susceptibility has been linked to several genetic markers and modifying several of the encoding genes to decrease disease susceptibility may result in difficult to predict, severe side effects. Since a targeted approach is hindered by a lack of knowledge of the determinants of susceptibility to $B s a l$, untargeted approaches may yield usable results, yet no proof of concept (neither for $B d$ nor $B s a l$, and in fact not for any infectious disease in vertebrates) exist. For selective breeding, the slow generation time of many urodeles (typically 3-4 years) precludes the rapid evolution of resistant populations. In the current absence of suitable markers, selecting for resistant individuals in captivity will require the use of large numbers of animals in (sub-)lethal animal experiments, which may raise ethical concerns. The European Union is currently reluctant to allow the use of genetically modified organisms in agriculture and targeted modification of the urodele genome, while increasingly feasible, will have to deal with regulatory issues before any such animal can be released into the wild. In contrast with $B d$, where response varies by species and sometimes populations (Bataille et al., 2015), there is no evidence of selection for individuals with increased disease resistance in infected, natural populations. For example, Stegen et al. (2017) demonstrated high susceptibility in the few remaining salamanders at an outbreak site and in 2018, several Bsal-infected salamanders were found dead at the index outbreak site in the Netherlands, where an estimated $0.1 \%$ of the animals has survived.

Selective breeding will probably be perceived by public opinion as more acceptable compared to genetic engineering (Garner et al., 2016) but 10 years of selective breeding of midwife toads has not resulted in any notable increase in their resistance against $B d$ (Bosch, unpublished). Both options could be explored but it will likely take decades before either could be shown as being successful - and probably only for a single species in that time frame. Selective breeding and genetic engineering, therefore, cannot be $_{\mathrm{se}} \mathrm{se}_{\mathrm{f}} \mathrm{as}_{\mathrm{n}}$ short-term /measures: to: $01 \mathrm{Am}$ 
address the urgency of Bsal mitigation, but at best as mid to long-term mitigation strategies.

\section{Post-exposure measures}

$B d$ was already widespread and had decimated many amphibian populations in several countries before its diagnosis. Epidemiological investigations of $B d$, causative agent of chytridiomycosis, were reported to have started 15 years after amphibian declines were initially observed, resulting in population declines, extirpations, and extinctions of approximately 200 species (Grogan et al., 2014). These measures have all been considered or research has been initiated for $B d$ mitigation. A few were implemented on various scales with varying levels of success (Woodhams et al., 2011; Garner et al., 2016). In some populations and countries affected by $B d$, host and pathogen have reached co-existence. Bsal was discovered much more recently, has not been detected in many countries and has been detected in relatively small regions in those affected. Therefore, the opportunity still exists to implement measures to avoid the incursion or delay the spread of this fungus. Also, if Bsal enters a naïve location, the efficacy of these methods may be high as the pathogen will likely be limited to a much smaller geographical area and fewer populations. However, the presence of two different forms of the fungus with one of them being the encysted environmentally resistant spore, makes success of these individual mitigation methods less likely.

Once there has been a Bsal incursion to a novel site, mitigation methods should focus on: 1. reducing the impact of the pathogen on susceptible amphibian species, 2. setting up conservation strategies to prevent population extirpation, and 3. preventing further Bsal spread. In exceptional cases, elimination of Bsal from the system may be attempted. However, the presence of animal and environmental reservoirs will likely preclude eradication from most ecosystems (Stegen et al., 2017). These postemergence approaches can be classified as measures to i) reduce the fungal load in the environment or host, and ii) safeguard populations from Bsal-induced extirpation. Such measures can be generally divided into in situ and ex situ approaches.

Short-term solutions are considered vital in temporarily preserving amphibian populations at risk (Garner et al., 2016). For example, as shown for $B d$, interventions with antifungals during an epidemic can alter infection dynamics and alleviate disease (Hudson et al., 2016; Geiger et al., 2017). However, in the absence of long-term disease management in situ, any short-term measure is unlikely to result in significant conservation success. This underscores the importance of further research into potentially effective mitigation measures. Here, we will discuss captive assurance colonies, in situ treatment of animals and the environment, creating barriers to limit Bsal spread and bioaugmentation.

Some bacteria have been detected to decrease $B d$ in vitro and in the field (Bletz et al., 2013). In the case of Bsal, some bacteria found on the host's skin have been able to reduce $B s a l$ in vitro (Bletz et al., 2018). Physical barriers appear to have reduced spread of both $B d$ and $B s a l$ from infected populations to naïve populations located within close proximity (Rodríguez-Brenes et al., 2016; Spitzen-van der Sluijs et al., 2018). Captive assurance colonies have had mixed outcomes in the case of $B d$ (Woodhams et al., 2011) and we expect will be just as challenging for Bsal, especially in terms of husbandry of such varied hosts and the host-pathogenenvironment triangle. In situ treatment of the environment/animals has also been carried out for $B d$ and has had some success (Woodhams et al., 2011; Garner et al., 2016). These in situ treatments of animals and the environment are expected to have some success in reducing the number of Bsal spores in the environ-

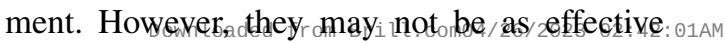


on the environmentally resistant spores. In addition, since less information is currently available on $\mathrm{Bsal}$, these mitigation measures are not likely to work better than they have for $B d$.

\subsection{Reducing the impact of Bsal}

\subsubsection{Reduce fungal load}

\subsubsection{Decontaminating and manipulating} environments Manipulating Bsal-infected environments by applying in situ intervention measures can be implemented to limit the spread of infection, reduce the impact of the pathogen and, by extension, increase amphibian survival. Environmental manipulations may be biological, physical or chemical and applying environmental interventions, such as the use of natural predators, antibiotics, fungicides, ponddrying, disinfectants and changes in ambient temperature are the most common methods used for the veterinary treatment of fungal diseases in aquaculture (Woodhams et al., 2011).

Hitherto, no environmental treatment has been applied to mitigate $B$ sal infection, but a few interventions have been shown to be effective to control $B d$. Using aquatic invertebrate 'micropredators' for the removal of $B d$ from the aquatic environment has been identified as a potential mitigation measure for aquatic or semiaquatic species and may also be potentially used against Bsal spores (Buck et al., 2011; Searle et al., 2013; Schmeller et al., 2014a). However, it is unclear to what extent the availability of other food sources influences the capacity of these micropredators to remove spores from the environment. $B d$-removing micropredators were found to contribute to creating refuges from chytridiomycosis (Blooi et al., 2017).

Eliminating the environmental reservoir of Bsal can be expected to contribute to controlling Bsal outbreaks. Crucial information is currently lacking about whether, how and to which extent Bsal (but equally $B d$ ) can persist in the environment in the absence of amphibian hosts. Identifying and enhancing micropredators which are able to reduce the number of Bsal spores in the environment may eventually lead to a reduction in the number of infected amphibians. The situation for $\mathrm{Bsal}$ is more complex compared to $B d$, since $B s a l$ produces two types of spores: zoospores and encysted spores. The latter, floating at the water-air interface, were shown to be less susceptible to predation (Stegen et al., 2017). Also, it is unclear whether a similar principle of predation is applicable to terrestrial systems. Currently, there is no proof of concept available of the impact of manipulating micropredator dynamics on amphibian chytrid dynamics in nature. Therefore, applying this approach to field situations requires caution since either selectively enhancing specific components or adding foreign organisms to ecosystems may alter foodwebs.

Physical methods, such as pond-drying and elevating the temperature of ponds, have been used to destroy $B d$ in the environment despite facing several challenges such as legal (protected species and habitats present), technical and epidemiological (for example: propensity of amphibians to escape from drying ponds, which may propagate pathogen spread). Physical methods are expected to have similar success in decreasing the Bsal zoospores in the environment while experiencing similar challenges as with $B d$. $B d$ does not survive drying (Johnson et al., 2003) and the efficacy of pond-drying, in relation to Bsal, will depend on how Bsal spores respond to desiccation. The efficacy of pond-drying and elevating the temperature of ponds will also depend on the type of Bsal spores present in the environment. These methods are not expected to work as efficiently on the environmentally resistant encysted form of the Bsal spore (Stegen et al., 2017).

Subjecting the fungus to temperatures and conditions which are unfavourable for growth and persistence of aquatic and other life stages, will result in its reduction. Johnson et al. (2003) showed in vitro that $B d$ is sensitive to desiccation and is fully cleared within $1 \mathrm{~h}$ of drying. However, in a field study by Bosch et al. (2015),

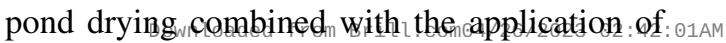


itraconazole did not eliminate $B d$ but merely decreased infection intensities for a short period of time. When these were combined with environmental disinfection, later, $B d$ was eradicated. Also, if pond drying is not done at an appropriate time it could result in dispersal of infected individuals, the destruction of the local ecology, including the death of tadpoles, eradication of local benign nano-, micro- and mesoplankton, which could negatively affect amphibian populations and other biodiversity. Finally, pond drying is more difficult to apply to important urodele habitats such as streams. On the other hand, for species that reproduce in ephemeral ponds, strategic artificial desiccation may result in the elimination of Bsal and of predators of amphibian larvae thus increasing juvenile survival and population persistence (Johnson et al., 2003; Woodhams et al., 2011). Any mitigation strategy that may potentially involve the degradation or destruction of habitat will require a careful and transparent costbenefit analysis (where "costs" is used to encompass any side-effect, including environmental damage).

Increasing the water temperature of amphibian breeding ponds, which can be achieved by removing canopy cover, can provide an important refuge from $B d$ (Freidenburg and Skelly, 2004; Forrest and Schlaepfer, 2011; Savage, Sredl and Zamudio, 2011; Scheele et al., 2014). Decreased shading of ponds is linked to lower $B d$ infection intensities (Raffel et al., 2010; Heard, et al., 2014). While this is cost-effective and would be beneficial to amphibian species which are tolerant of or even prefer higher temperatures (Langton et al., 2001), the relevance for European urodeles can be questioned. Increasing water temperatures may be expected to be poorly tolerated by heat-sensitive species and its relevance for lotic ecosystems is very uncertain. Besides issues of feasibility, water temperatures should be higher than $25^{\circ} \mathrm{C}$ to kill Bsal (Blooi et al., 2015a), exceeding the thermal preferences of many European urodeles. While its efficacy has yet to be demonstrated, it may be worth considering the option of decreased shading of terrestrial habitats as a supportive action to reduce environmental Bsal loads through surface heating and desiccation. Again, competing objectives such as revegetation targets, the impact on other species and broader issues such as forestry interests will need to be taken into account.

The environmental application of chemical treatments is another option for fungal disease mitigation. Applying the disinfectant Virkon $\mathrm{S}$ $1 \%$ (as experimented by Bosch et al., 2015 at the breeding sites of Alytes muletensis) or adding sea salt to increase salinity (Stockwell, Clulow and Mahony, 2012, 2015) were able to eliminate or lower $B d$ infection in the aquatic environment and may be promising strategies for inhibiting Bsal growth. Fungicides have only been used in simple single-host systems and controlled, isolated habitats (Garner et al., 2016) and it remains to be demonstrated whether they could work in more complex habitats. In addition to these potential limitations to their in situ application, preliminary studies indicate that fungicides and disinfectants are ineffective in curbing Bsal (Van Rooij et al., 2017).

Creating saline refuges in amphibian environments has been suggested as a feasible conservation method to control $B d$ infections in anurans, being relatively cheaper than other methods. While this method functions by disrupting chytrid growth and motility (Stockwell, Clulow and Mahony, 2015), it has been shown to have deleterious effects in aquatic organisms (Karraker, Gibbs and Vonesh, 2008; Denoël et al., 2010; Karraker and Gibbs, 2011; Tollefsen et al., 2015; Jones et al., 2016). It will also be difficult to apply to lentic systems, and like with fungicides, its effects in terrestrial systems remain unknown.

The methods used in environmental manipulation may create tolerance to, or resistance against, Bsal among small isolated groups of amphibians and also provide sanctuaries for focal species deemed highly vulnerable and of particular conservation concern. However, they may be less effective $_{\mathrm{N}}$ mitigation measures for $_{2}$ o1 AM 
amphibians with large ranges and their effects may be variable in complex habitats. Environmental manipulation may face many legal barriers and may conflict with other conservation priorities. For example, manipulations in protected areas or with negative effects on protected species or habitats may require environmental impact assessment and public consultation.

\subsubsection{In situ treatment of the amphibian} host There have been no studies to date that have investigated the in situ treatment of amphibians infected with Bsal. Hudson et al. (2016) and Geiger et al. (2017) evaluated the impact and feasibility of in situ treatment using the antifungal drug itraconazole to mitigate $B d$ induced amphibian chytridiomycosis. Firstly, it is easier to treat $B d$-infection than Bsal using itraconazole exclusively. The results from Hudson et al. (2016) and Geiger et al. (2017), indicated that itraconazole treatment decreased the probability of $B d$ infection and the mortality rate of infected animals, however, as soon as treatment was ceased, all benefits disappeared and the infection and mortality rate increased to those of untreated individuals. This suggests treating infection does not induce any protective immune responses to $B d$ (Hudson et al., 2016) and, when based on empirical data without proper toxicity assessment, may even have detrimental effects on the survival of a species (Loyau et al., 2016). This in situ treatment method, while labour-intensive and limited to amphibian species for which recapture rates are relatively high, could be used as a short-term conservation tool to reduce the mortality caused by $B d$ or $B s a l$ during periods of high disease risk or to gain time during disease outbreaks while a more permanent solution is identified (e.g. Hudson et al., 2016; Geiger et al., 2017). Effectively treating a $B$ sal-infected fire salamander population would require an almost total coverage of the population, combined with a $100 \%$ effective treatment to interrupt transmission (Canessa et al., 2018). Anything less might result in adverse effects: prolongation of the survival of infected animals would increase the potential for disease spread within and outside the focal population. Such an effective treatment can be done only ex situ, since it requires repeated and consistent application of either the use of relatively high temperatures $\left(25^{\circ} \mathrm{C}\right)$ or a combination of the antimicrobial drugs polymyxin $\mathrm{E}$ and voriconazole (Blooi et al., 2015a, 2015b). In practice, this would mean removal of all infected animals from their habitat and release after treatment.

\subsubsection{Safeguard populations}

\subsubsection{Bioaugmentation and vaccination For} vaccination, see section 2.4.1. Provided a protective vaccine can be developed, this could be applied during an outbreak to limit losses. For bioaugmentation, see section 2.4.2. Besides being a preventative approach, micro-organisms, either alone or in mixtures, could potentially be used therapeutically during a Bsal outbreak to limit the impact of infection.

\subsection{Preventing further Bsal spread}

\subsubsection{Reduce fungal load}

3.2.1.1. Removal of hosts The removal of infected or even of all susceptible hosts (including non-infected) from a population might be a mitigation strategy worth exploring. In susceptible species, the eradication of Bsal is likely to require the removal of a substantial proportion $(>90 \%)$ of the focal hosts as well as any other species in the same area that are acting as reservoirs (Canessa et al., 2018). Moreover, Bsal has been shown to persist in the environment in the absence of amphibian hosts. This possibly explains, at least in part, the high probability that a susceptible population will be extirpated by Bsal (Stegen et al., 2017). It also means that eradication from a site is unlikely, although the likelihood of this will be increased the longer the site is maintained free of amphibians. However, even if eradication cannot be achieved, removing infected animals reduces the probability of spillover of Bsal to neighbouring populations

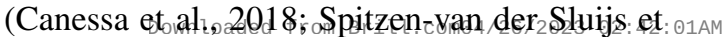


al., 2018). The reaction of the public to host removal may be expected to vary according to the fate of the animals removed. Translocation of these animals to other sites should be strongly discouraged and reintroduction at the original site is only acceptable after Bsal eradication has been demonstrated and maintained for a reasonable period of time. Otherwise, this may result in flare-ups of infection, with the likelihood of further spread to neighbouring sites. While culling may well be the most rational option, and is well accepted in OIE disease control programmes, this is more likely to meet adverse reactions compared to transferring the animals to captivity with subsequent treatment.

\subsubsection{Safeguarding populations}

\subsubsection{Creating barriers to the spread of} Bsal Simple mathematical models suggest that Bsal will spread rapidly in a homogeneous landscape (Schmidt et al., 2017). Yet, this is not what was observed near the Bsal index site. In fact, there are indications that the natural (autonomous) spread of Bsal is relatively slow and can be interrupted by barriers that limit dispersal of infected salamanders such as rivers, highways, unsuitable habitat and fences (Spitzen-van der Sluijs et al., 2018). That study did not identify biotic or abiotic vectors of $\mathrm{Bsal}$, but its results suggest that the local movement of infected hosts may be crucial in the dispersal of Bsal over short distances, whilst human-mediated transmission will be the most important pathway of longdistance spread. Understanding the fundamentals of range expansion would offer opportunities for developing barrier-based strategies. This may be used to protect uninfected (sub)populations through isolation, or to contain outbreaks if caught at an early stage. Such measures may be effective in the short-term and could significantly reduce the risk of spread of Bsal, but their efficacy in the mid to long-term is unclear, given the non-continuous distribution pattern of Bsal. This pattern is characterized by often large distances between outbreak sites, which are highly unlikely to be bridged by infected salamander hosts within the observed timescales. Although human-mediated spread may at least in part explain the long distance dispersal of Bsal, between-site transmission is currently poorly understood and biotic (e.g. birds) and abiotic dispersers cannot be currently excluded. However, the persistence of an uninfected fire salamander population for over 8 years only $800 \mathrm{~m}$ from the Bsal index outbreak suggests that managing landscapes, exploiting existing barriers and creating meaningful barriers may be a relatively low-cost option worth exploring.

\subsection{Setting up conservation strategies to prevent population extirpation}

\subsubsection{Safeguarding populations}

\subsubsection{Reintroduction and captive breeding} Introductions to restore original populations require prior removal or management of the Bsal threat in the wild (IUCN, 2013; Muths and McCallum, 2016). Affected host species could be reintroduced, either with translocations from other wild populations or using individuals that have been captured and treated or bred in captivity. Also, reinforcement of extant populations may be implemented in combination with other mitigation actions that augment resistance to infection or disease. More radical options might also include the assisted movement of threatened species to areas of lower Bsal risk (Gagliardo et al., 2008). Experience shows that efforts to establish captive assurance colonies should be initiated early in the mitigation process (Martin et al., 2012). Given resource limitations, prioritisation is inevitable and conservation units (from population to species level) have to be defined (see section 4.3). Establishing captive assurance colonies is currently the only effective action to preserve species with small ranges, or otherwise valuable populations, following invasion by Bsal. Although this is a feasible option, any such action should be planned and executed carefully and conducted from the outset, with an explicit view to future reintroduction options $_{m}\left(\right.$ Canessa $_{0}$ et $_{2} \mathrm{al}_{202} 2016$ ) $_{2: 01 \mathrm{Am}}$ 
This includes keeping animals under high levels of biosecurity as necessary to prevent exposure to other pathogens that might eventually be released into the wild with the animals or their offspring, as was the case with the contamination of Mallorcan midwife toads by $B d$ (Walker et al., 2008). Also, captive assurance colonies need to have informed genetic and veterinary management - which often requires the involvement of multiple centres - and to be run in accordance with IUCN guidelines (Pessier et al., 2014). Protocols for such assurance colonies and resources should preferably be in place for all high-risk populations or species. Expertise to maintain and breed $\mathrm{Eu}-$ ropean urodeles is widely available, although largely limited to the private sector (e.g. DGHT, AG Urodela). Currently, only one European species is propagated consistently in the framework of a captive assurance colony, combined with reintroduction efforts: the Montseny brook newt (Calotriton arnoldi, LIFE-Tritó project, http://lifetritomontseny.eu/). Such captive assurance colonies would benefit from participation and collaboration of professional organisations (zoos, aquaria, represented by EAZA), research institutions and the private sector (Pasmans et al., 2017).

\section{Supporting actions}

The actions discussed above seek to achieve a conservation objective, namely to ensure the persistence of populations or species by preventing the introduction of Bsal or by mitigating its effects if it is introduced. To be effective, such actions need to be informed by knowledge of Bsal host-pathogen dynamics and information on Bsal spread, host conservation status and outcomes of any previously implemented action. Moreover, mitigation strategies will require many decisions to be taken at different levels, from the global to the local scale, with widely differing levels of available resources. Here, we detail several actions that might assist the broader mitigation process. It must be noted that these actions are only useful in supporting the mitigation actions discussed above: for example, monitoring alone will not abate the negative impacts of $\mathrm{Bsal}$, but the data collected are vital in understanding where and how to implement conservation interventions.

\subsection{Early-warning system}

An early-warning system is a valuable tool for rapid $B s a l$ detection and response. It consists of Bsal notification points that are responsible for national or regional surveillance for, and the collection of, dead amphibians (by local volunteers) and the determination of the cause of death. Early warning systems were largely unimplemented for a long period during $B d$ 's spread since the cause of amphibian mortality remained elusive. Epidemiological investigations of $B d$ were reported to have started 15 years after amphibian declines were initially observed, resulting in population declines and extirpations, and extinctions of approximately 200 species (Grogan et al., 2014). A sensitive and specific diagnostic technique that shows high interlaboratory reproducibility of results is key to an efficient early-warning system and, for Bsal, consists of quantifying Bsal genome equivalents in non-invasively collected skin swabs (Blooi et al., 2013; Thomas et al., 2018). Once more information on the disease killing amphibians became known, a sensitive and specific test with interlaboratory reproducibility for detection of $B d$ was developed by Boyle et al. (2004). Presence of $B d$ was detected on museum specimens collected over a century prior to detection of chytridiomycosis infection. As part of a project, funded by the European Commission (Tender ENV.B.3/SER/2016/0028, Mitigating a new infectious disease in salamanders to counteract the loss of biodiversity, http://bsaleurope.com/), notification points have been set up in Belgium, France, Germany, the Netherlands, Spain, Italy, and the UK. The setup of an effective early_warning system $_{2}$ requires: 01AM 
informing, and active involvement of all stakeholders (including the public), building sufficient diagnostic capacity and efficient data management, including proper reporting to the OIE (Bsal was listed in 2017 by the OIE).

Detecting environmental DNA of target organisms (eDNA) (Taberlet et al., 2012) is now widely used for biodiversity inventories, and recommended for use in the early detection of invasive species (Darling and Mahon, 2011) and aquatic pathogens (Guy et al., 2003; Huver et al., 2015). For $B d$, eDNA detection in water was shown to be efficient in detecting occupancy of ponds by $B d$ (Walker et al., 2007; Schmidt et al., 2013). The applicability of eDNA for detecting $B s a l$ is currently uncertain as it would require detecting pathogen DNA in more complex matrices such as forest soil. Standard eDNA detection in water would be useful for detection of Bsal during the aquatic phase of urodelan life. However, many salamanders in Europe are terrestrial, thus the testing for eDNA would need to be carried out in matrices more complex than water.

Regardless of the diagnostic method used, an efficient early-warning system should include active and passive disease surveillance. We here use the terms pathogen and disease surveillance as ongoing recordings of Bsal and Bsalassociated disease in wild amphibian populations. "Passive pathogen and disease surveillance" is used for the recording of Bsal and Bsal disease presence as they occur (reactive) and "active pathogen and disease surveillance" for targeting individuals to detect Bsal and Bsal disease presence (proactive). Active and passive surveillance were implemented for $B d$ pathogen and disease in several countries in Europe (Garner et al., 2005). $B d$ spread to many countries before information was available on the cause of amphibian mortality in those locations therefore, many measures which have been implemented as part of the early warning system against the incursion of Bsal were not able to be implemented in those environments but may still be implemented in countries or regions free of $B d$.

\subsubsection{Passive disease surveillance. Passive} surveillance of Bsal outbreaks is currently done by the reporting of opportunistically observed suspect cases to a regional hotline for further examination. Observers can be professionals or lay people. Passive surveillance can enable the detection of disease across large spatial scales, but the likelihood of detection depends on many factors such as the mere detectability of the affected species (many urodele species are secretive), the degree of observer effort (e.g. number of observers and amount of time each observer spends looking for diseased animals), the ability of observers to identify disease and the likelihood that any diseased animals detected will be reported to the relevant authority (Kéry and Schmidt, 2008; Buckland et al., 2010; Lawson, Petrovan and Cunningham, 2015). Key example of public reporting leading to disease detection in this context is detection of the index outbreak of Bsal in the Netherlands, the first signs of which were noted as a steep population decline in the framework of a long-term salamander monitoring campaign. Passive surveillance currently seems to be the most feasible approach for detecting the occurrence of Bsal disease outbreaks in Europe, at least in species with large ranges (EFSA, 2018). Through the European Union Bsal tender, passive surveillance for amphibian diseases recently initiated at the national level in Belgium, France, Germany, Italy, the Netherlands, Spain, Switzerland and has been ongoing at the national level in the United Kingdom since 1989 (Lawson, Petrovan and Cunningham, 2015) (http://bsaleurope.com/).

\subsubsection{Active disease surveillance. Implem-} enting a thorough system of active surveillance throughout Europe would be the most reliable way to determine the current distribution of Bsal infection in the wild; however, such a system would require enormous amounts of resources that may need to be diverted fromother duses It $_{3}$ may doe more efficient: $01 \mathrm{Am}$ 
to concentrate active surveillance and monitoring within and around localities where a disease outbreak consistent with Bsal chytridiomycosis is detected (EFSA, 2018). In Austria, Belgium, Croatia, Czech Republic, France, Germany, Portugal, Slovenia, Spain, Switzerland, the Netherlands and the UK, non-systematic active surveillance has been carried out on an ad hoc basis (EFSA, 2018). Active surveillance for Bsal is currently done by proactively sampling amphibians for presence of Bsal infection or for Bsal disease itself in a quantitatively adequate number of populations. Since Bsal outbreaks are characterized by collapses of urodele populations, the least costly option is to monitor sentinel populations of susceptible host species for signs of population declines. Such actions can be designed as citizen science projects (Dickinson et al., 2012) coordinated by relevant scientific entities. Integration of professional and citizen-science monitoring schemes may broaden the coverage and amount of data collected, particularly if optimised spatially and temporally (Morán-Ordoñez et al., 2018). Longitudinal monitoring of amphibian populations is key to interpret disease findings and provides the necessary baseline information to evaluate disease impact.

\subsection{Monitoring of ongoing population declines and past outbreak sites}

Populations already in decline and adjacent ones, require special attention via monitoring. (Grogan et al., 2014; Ficetola et al., 2018). Monitoring of the host population and the pathogen should continue well after host populations are ascertained to have declined or been extirpated, to provide information about Bsal's persistence in the environment and/or in alternative hosts. In the future, this will provide useful information for the development of post-outbreak restoration protocols, such as reintroductions.

\subsection{Conservation prioritisation}

Scientific evidence is essential to narrow knowledge gaps and inform the decision-making process as to which species are prioritised. However, clarifying the decision context (who decides whether a species should be allocated resources, who provides those resources, who implements the action) is just as important (Game, Kareiva and Possingham, 2013). Prioritisation of Bsal mitigation actions at the European level would need to follow these four steps: (1) definition of priorities, based on EU, state or local legislation, or criteria describing the importance of species and subspecies in terms of e.g. genetic diversity, ecosystem function or cultural values; (2) a complete risk assessment of the impacts of Bsal on all species; (3) evaluation of the benefits and costs of potential actions for each species by an expert panel including scientists, managers and policy-makers; (4) identification of priority species (selection and listing of specific species that fit the criteria for prioritisation per point 1 above). In the current situation, information about species-specific risks and actions is urgently needed.

Thirty-four urodele species occur across the 27 EU member states (European Red List, 2018). Given the limited resources available, it is unlikely that full protection against $\mathrm{Bsal}$ impacts could be provided to all those species in all those countries (also considering the intraspecific variants of conservation interest). Several quantitative methods for transparent conservation prioritisation have been developed (Brooks et al., 2006; Schmeller et al., 2008; Joseph, Maloney and Possingham, 2009; Moilanen, Wilson and Possingham, 2009; Gerber et al., 2017; Grant et al., 2017). Prioritisation is the result of a trade-off between the potential for successful conservation (the actions available and their chances of success, given the risk to a species) and the preferences and constraints of the decision makers, such as the conservation value attributed to a species, its distribution range, available resources, dunwanted deffects nn/ecosystems; : 01AM 
and attitudes to risk (Joseph, Maloney and Possingham, 2009; Tulloch et al., 2015). Understanding these components and treating them appropriately is key to a transparent decisionmaking process (Game, Kareiva and Possingham, 2013).

These trade-offs are also relevant in the case of Bsal. First, priorities will inevitably depend on the decision context. For example, S. salamandra may not be considered a conservation priority at the EU level or in many countries in which it is common. Because of its restricted geographical range in the Netherlands and the fact that it has been severely affected by Bsal, $S$. salamandra is prioritised for conservation there (Spitzen-van der Sluijs et al., 2013). Many possible criteria for prioritisation have been suggested, from genetic representativeness (Isaac et al., 2007) to range-wide relevance of local declines (Schmeller et al., 2008, 2014b) to cultural values (Pollard et al., 2014). The object of prioritisation, is utilising feasible mitigation measures which are available for conserving species: if actions to mitigate $\mathrm{Bsal}$ are not available or feasible in practice, species priorities have little meaning (Brown et al., 2015). Also, the management of more common species that may for example serve as disease reservoirs needs to be implemented so that primary mitigation actions can be effective (Dobson, 2004; Stegen et al., 2017). This also applies to monitoring, where sentinel species might be prioritised for surveillance even though they are not conservation priorities (Halliday et al., 2007).

\section{Conclusion: critical research gaps and future actions}

Bsal mitigation is surrounded by a high level of uncertainty, however, this should not result in protracted decision-making periods or inaction as this will lead to certain biodiversity loss. From a pragmatic conservation perspective, the main objective of mitigating Bsalinduced chytridiomycosis should be to preserve susceptible amphibian species and populations and protect biodiversity, rather than the eradication of Bsal in the wild per se. In this sense, any single method is unlikely to accomplish the desired conservation outcome (Gagliardo et al., 2008; Garner et al., 2016). Each approach has its benefits and limitations; therefore, a combination of methods may have the best chance of success.

Given the lack of verified, reliable disease mitigation options, we advise that pre-emptive measures, aimed at reducing pathogen spread and further pathogen introductions by a combination of trade restrictions, biosecurity measures and eliminating the captive Bsal reservoir are enacted as a matter of urgency. The set-up of a long-term population monitoring network is key in the early recognition of changes in population sizes, which allows estimating disease impact and evaluation of population recovery. Developing and maintaining a robust early warning system based on passive surveillance will be highly beneficial for the implementation of these Bsal control measures. Another important supporting action is the monitoring of host population (size) and Bsal-infection dynamics (prevalence, mortality) in known outbreak areas with a view to making apropos conservation decisions. The final supporting action is the development of an evidence-based emergency action plan for at-risk species.

In case of a Bsal outbreak, actions that can be taken should focus on disease containment and preserving valuable populations or species where relevant. Disease containment may consist of a rigorous combination of:

1) limiting opportunities for pathogen dispersal, for example by fencing off areas and restricting access to prevent entry of humans, large mammals, waterbirds and anurans.

2) eliminating potential Bsal environmental reservoirs (drying and disinfection of ponds).

3) identifying and eliminating potential Bsal amphibian reservoirs by consistent and repeated removal of Bsal hosts. $02: 42: 01 \mathrm{AM}$ 
4) delineating the outbreak by intensive monitoring of neighbouring populations for Bsal infection and population declines by repeated sampling using skin swabs and population monitoring.

Establishment of ex situ assurance colonies is the most immediately viable course of action and the only option available currently to preserve populations or even species at risk from Bsal. However, this must be implemented with the primary intention of developing a long-term protection strategy for effective and sustainable reintroduction. The latter needs applied conservation studies into sustainability, feasibility and effectiveness of mitigation actions (table 2).

The implementation of current legislation and the above mentioned recommendations is likely to reduce introduction events of Bsal and may contain the disease at novel outbreak sites, but does not provide long-term, sustainable solutions for infected systems. This will require closing the following critical knowledge gaps:

1) introduction pathways: while it is currently assumed that amphibian trade is key in the global dispersal of amphibian-infecting chytrids (Martel et al., 2014; O'Hanlon et al., 2018), proven examples of this are rare (Walker et al., 2008). Identifying crucial components of amphibian-associated pathways for introducing chytrids (not a priori excluding any biotic or abiotic vector) would increase the efficacy of measures aimed at preventing further introductions.

2) understanding pathways of the dispersal of Bsal between populations. Preventing the further spread of Bsal in Europe from the existing outbreak sites requires knowledge of mechanisms underpinning this pathogen's spread. While dispersal through infected amphibian hosts seems important at short distances (Spitzen-van der Sluijs et al., 2018), humanmediated spread may be key on a larger spatial scale. However, the possible contribution of other biotic (e.g. migratory birds, large mammals) and abiotic (e.g. waterways, wind) vectors is not yet known.

3) understanding Bsal reservoirs is crucial to any in situ control programme: an eight year follow-up of the Bsal index outbreak demonstrates very low prevalence, with very low infection loads in the supposed reservoir host (Alpine newt), suggesting that the existence of a different, non-amphibian reservoir of Bsal may be necessary to maintain Bsal in this ecosystem. Identifying critical components in an affected ecosystem that allow Bsal persistence could greatly contribute to any eradication action.

4) understanding host susceptibility to Bsal infection. Any action aimed at increasing resistance against infection will benefit from a thorough understanding of the host-pathogenenvironment interaction, knowledge of which is currently in its infancy. Understanding crucial events like adhesion and intra-epidermal pathogen proliferation from a host, pathogen and environment perspective could open opportunities for vaccination, bioaugmentation, environmental augmentation and the eventual creation of more resistant host lineages.

Acknowledgements. This work was supported by the European Commission (Tender ENV.B.3/SER/2016/0028, Mitigating a new infectious disease in salamanders to counteract the loss of biodiversity). E.V. and S.C. are supported by the Research Foundation Flanders (FWO grants 12E6616N and FWO16/PDO/019 respectively). D.S.S. and A.L. were supported by the Belmont Forum (DFG-SCHM 3059/6-1) and the Axa Research Fund through the project GloMEC. M.C.F. was supported by NERC (NE/K014455/1), the Leverhulme Trust (RPG-2014-273), the Morris Animal Foundation (D16ZO-022) and the Canadian CIFAR "Fungal Kingdom" programme. T.W.J.G. was supported by NERC (NE/S000992/1, NE/N009967/1). S.L., S.S., M. Vences, M. Veith and N.W. were supported by the Federal Agency for Nature Conservation $(\mathrm{BfN})(\mathrm{R}+\mathrm{D}$ project "Monitoring und Entwicklung von Vorsorgemaßnahmen zum Schutz vor der Ausbreitung des Chytridpilzes Batrachochytrium salamandrivorans ("Bsal") im Freiland"). S.L., N.W., Michael Veith and Miguel Vences were also supported by a seed grant from Deutsche Bundesstiftung Umwelt (DBU).

Supplementary material. Supplementary material is available online at: 
Table 2. Advantages and limitations of mitigation and support actions against Bsal.

\begin{tabular}{lll}
\hline Mitigation action & Advantages & Disadvantages
\end{tabular}

Trade restrictions: importation of live amphibians into the EU

Trade restrictions within EU

Eradication of Bsal from captive urodeles

Biosecurity measures

Vaccination

Bioaugmentation
Likely to greatly reduce chances of further Bsal introduction in EU

Associated costs low in case of ban Relative ease of implementation and control

Likely to greatly reduce chances of $\mathrm{Bsal}$ spread between EU member states Relative ease of implementation Associated costs low in case of ban

Elimination of Bsal reservoir with reduced likelihood of pathogen pollution, part of a "clean trade" programme

Improves animal welfare of captive urodeles

Likely to reduce chances of spread of $\mathrm{Bsal}$ and other amphibian pathogens

Protocols for disinfection already available Raises awareness

Implementation of field protocols for working with amphibians already in place in many EU countries

Could be used for prevention and during outbreaks

Probably viewed as positive by public opinion

Could be used for prevention and during outbreaks

May be transferable across generations Probably viewed as positive by public opinion
May promote illegal trade

As a stand-alone measure does not prevent Bsal spread within EU

Associated costs are significant in case of implementing quarantine and entry control measures

May promote illegal trade

Difficult to control

As a stand-alone measure does not prevent Bsal spread within member states

Associated costs significant in case of implementing quarantine and entry control measures

Costs associated with education, screening, diagnosis and treatment

Depends on willingness of hobby sector to cooperate

May conflict with commercial interests Depends on willingness of all stakeholders to implement properly

Considered a burden

Use of chemicals may have adverse effects on humans and environment

Costs associated with communication and implementation

Cannot control for all potential routes of transmission (e.g. wildlife)

No vaccines available

Vaccine development very expensive,

long-term and uncertain

Proof of concept with wild type Bsal strain failed

Costs associated with production and application

Regulatory issues

Generally not transferable across generations

Imperfect treatments that only create tolerance while not interrupting transmission could have adverse effects by increasing spread

May need to target multiple hosts in diverse amphibian communities

Currently not available

Development costly and uncertain

No proof of concept

Regulatory issues

Imperfect treatments that only create tolerance while not interrupting transmission could have adverse effects by increasing spread

May need to target multiple hosts in diverse amphibian communities 
Table 2. (Continued.)

Mitigation action Advantages Disadvantages

Selective breeding

Environmental treatment with disinfectants / antimycotics

Environmental manipulation

In situ treatment

Reintroduction after Bsal eradication

Creating barriers to pathogen dispersal
Offers perspectives to long-term increased disease resistance

Proven effective in single host system for $B d$ May lower infection pressure and reduce likelihood of transmission
Currently no markers available for marker assisted breeding

Genetic engineering fraught with regulatory and public opinion issues

Development will take several generations, depending on species

No proof of concept

Possibly not transferable between species

Requires intensive genetic population management

Costs associated with producing breeding stock and genetic management

No proof of concept for Bsal

Bsal may be less sensitive to disinfectants in terrestrial environment

Efficacy questionable in complex systems

Adverse effects on environment

Not suitable for large scale application

Regulatory issues

Societal issue of antimycotic resistance

Costs associated with products and application Feasibility dependent on application scheme Imperfect treatments that only create tolerance while not interrupting transmission could have adverse effects by increasing spread

May reduce infection pressure and likelihood of transmission

May allow host species to compensate Bsal-related mortality (e.g. by increased recruitment)

Potential adverse effects on environment No proof of concept for Bsal

Environmental drivers for $\mathrm{Bsal}$ infections not known

Costs associated with habitat manipulation and maintenance

May eliminate Bsal from infected animals Probably viewed as positive by public opinion

Costs associated with treatment

Labor intensive

Unlikely that all infected animals are caught for treatment, which is necessary to curb infection at population level

Bsal infection may recrudesce after treatment Imperfect treatments that only create tolerance while not interrupting transmission could have adverse effects by increasing spread

Directly reinforces remnants of affected populations

Requires ex situ captive assurance colonies (see below)

Probably positively viewed by public opinion Requires thorough follow up of reintroduction event, with associated costs of population and disease monitoring

Risk of failure and increased pathogen proliferation if $\mathrm{Bsal}$ is not eradicated from the environment

Costs associated with installation and maintenance

Bsal spread between site

May create disease free pockets

Barriers may have considerable failure rates and target only part of all potential vectors May conflict with local infrastructure May have adverse effects on non-target species Regulatory issues 
Table 2. (Continued.)

\begin{tabular}{lll}
\hline Mitigation action & \multicolumn{1}{c}{ Advantages } & \multicolumn{1}{c}{ Disadvantages } \\
\hline Culling & $\begin{array}{l}\text { May reduce Bsal dispersal } \\
\text { Culling of reservoir hosts may reduce } \\
\text { community-level epidemic and assist } \\
\text { persistence of species of conservation } \\
\text { priority }\end{array}$ & $\begin{array}{l}\text { Costs associated with culling } \\
\text { Unlikely that a sufficient proportion of } \\
\text { animals can be captured }\end{array}$ \\
& $\begin{array}{l}\text { High likelihood of adverse reactions of } \\
\text { public opinion } \\
\text { Bsal may persist outside of managed hosts } \\
\text { Regulatory issues } \\
\text { No action }\end{array}$ & $\begin{array}{l}\text { May need to target multiple hosts in diverse } \\
\text { amphibian communities }\end{array}$ \\
& $\begin{array}{l}\text { Possibility of population extirpation or } \\
\text { species extinction } \\
\text { Potential conflict with Habitat's Directive } \\
\text { For broad range species with focal } \\
\text { population declines if } \text { Bsal is } \\
\text { spontaneously eradicated }\end{array}$ & $\begin{array}{l}\text { High likelihood of adverse reactions of } \\
\text { public opinion }\end{array}$ \\
\hline
\end{tabular}

\begin{tabular}{lc}
\hline Support action & Advantages \\
\hline Early warning system & Allows rapid detection and response
\end{tabular}

Passive surveillance

Active surveillance pre-outbreak

Active surveillance post-outbreak

Species prioritization

Captive assurance colonies

Monitoring
Large spatial scale possible Low associated costs

Opportunity to collect data on host population size and distribution

Monitoring infection dynamics highly informative to mitigation (e.g. pathogen persistence versus eradication)

Allows efficient, evidence based allocation of resources for conservation

Clarifies which species are conservation priorities (e.g. susceptible species), which are management priorities (e.g. reservoirs)

Ensures species survival IUCN guidelines available Captive maintenance of urodeles relatively cheap

High likelihood of detecting mortality events and population declines

Detects declines regardless of the causative agent

Public involvement raises awareness
Disadvantages

Associated costs for efficient operation: diagnostic capacity, data management, communication

Likelihood of outbreak detection highly variable

Requires intensive communication efforts and sufficient diagnostic capacity

Large-scale implementation problematic Associated costs of coordination, monitoring and sampling

Associated costs of coordination, monitoring and sampling in a contaminated environment Requires rigorous application of biosecurity measures

Requires the availability of detailed information on disease ecology for several urodele taxa that is currently lacking

Inaccuracies may have far-reaching consequences for species conservation

Costs associated with coordination, infrastructure and maintenance

Requires genetic management Relevance questionable if no perspective for future re-introduction

Regulatory issues

Requires proper biosecurity

Most likely requires prioritization

Husbandry techniques may need to be developed for some species

Costs associated with coordination and fieldwork

For financial reasons, often involves the use of volunteers, which may reduce manageability 


\section{References}

199/2017. (VII. 10.) Korm. rendelet (2017) a kedvtelésből tartott állatok tartásáról és forgalmazásáról szóló 41/2010. (II. 26.) Korm. rendelet és a veszélyeztetett vadon élő állat - és növényfajok nemzetközi kereskedelmét szabályozó nemzetközi és európai közösségi jogi aktusok végrehajtásának egyes szabályairól szóló 292/2008. (XII. 10.) Korm. rendelet módosításáról. Retrieved from https://net.jogtar. hu/jr/gen/hjegy_doc.cgi?docid=A1700199.KOR\&time shift=fffffff \& txtreferer=00000001.TXT.

Auliya, M., Garcia-Moreno, J., Schmidt, B.R., Schmeller, D.S., Hoogmoed, M.S., Fisher, M.C., Pasmans, F., Henle, K., Bickford, D., Martel, A. (2016): The global amphibian trade flows through Europe: the need for enforcing and improving legislation. Biodivers. Conserv. 25: 2581-2595.

Bataille, A., Cashins, S.D., Grogan, L., Skerrat, L.F., Hunter, D., McFadden, M., Scheele, B., Branelly, L.A., Macris, A., Harlow, P.S., Bell, S., Berger, L., Waldman, B. (2015): Susceptibility of amphibians to chytridiomycosis is associated with MHC Class II conformation. Proceedings of the Royal Society B Biological Sciences 282: 20143127.

Bates, K.A., Clare, F.C., O'Hanlon, S., Bosch, J., Brookes, L., Hopkins, K., McLaughlin, E.J., Daniel, O., Garner, T.W.J., Fisher, M.C., Harrison, X.A. (2018): Amphibian chytridiomycosis outbreak dynamics are linked with host skin bacterial community structure. Nat. Commun. 9: 693.

Berger, L., Speare, R., Kent, A. (1999): Diagnosis of chytridiomycosis in amphibians by histologic examination. World Wide Web file. Retrieved from http://www.jcu.edu.au/school/phtm/PHTM/frogs/histo/ chhisto.htm.

Berger, L., Speare, R., Daszak, P., Green, D.E., Cunningham, A.A., Goggin, C.L., Slocombe, R., Ragan, M.A., Hyatt, A.D., McDonald, K.R., Hines, H.B., Lips, K.R., Marantelli, G., Parkes, H. (1998): Chytridiomycosis causes amphibian mortality associated with population declines in the rain forests of Australia and central America. Proc. Natl. Acad. Sci. U.S.A. 95: 9031-9036.

Beukema, W., Martel, A., Nguyen, T.T., Goka, K., Schmeller, D.S., Yuan, Z., Laking, A.E., Nguyen, T.Q., Lin, C.-F., Shelton, J., Loyau, A., Pasmans, F. (2018): Environmental context and differences between native and invasive observed niches of Batrachochytrium salamandrivorans affect invasion risk assessments in the Western Palaearctic. Divers. Distrib. 24: 1788-1801.

Bletz, M.C., Loudon, A.H., Becker, M.H., Bell, S.C., Woodhams, D.C., Minbiole, K.P.C., Harris, R.N. (2013): Mitigating amphibian chytridiomycosis with bioaugmentation: characteristics of effective probiotics and strategies for their selection and use. Ecol. Lett. 16: 807-820.

Bletz, M.C., Kelly, M., Sabino-Pinto, J., Bales, E., Van Praet, S., Bert, W., Boyen, F., Vences, M., Steinfartz, S., Pasmans, F., Martel, A. (2018): Disruption of skin microbiota contributes to salamander disease. Proc. Biol. Sci. 285 (1885).
Blooi, M., Pasmans, F., Longcorre, J.E., Spitzen-van der Sluijs, A., Vercammen, F., Martel, A. (2013): Duplex real-time PCR for rapid simultaneous detection of Batrachochytrium dendrobatidis and Batrachochytrium salamandrivorans in amphibian samples. J. Clin. Microbiol. 51: 4173-4177.

Blooi, M., Martel, A., Haesebrouck, F., Vercammen, F., Bonte, D., Pasmans, F. (2015a): Treatment of urodelans based on temperature dependent infection dynamics of Batrachochytrium salamandrivorans. Sci. Rep. 5: 8037.

Blooi, M., Pasmans, F., Rouffaer, L., Haesebrouck, F., Vercammen, F., Martel, A. (2015b): Successful treatment of Batrachochytrium salamandrivorans infections in salamanders requires synergy between voriconazole, polymyxin E and temperature. Sci. Rep. 5: 11788.

Blooi, M., Laking, A.E., Martel, A., Haesebrouck, F., Jocque, M., Brown, T., Green, S., Vences, M., Bletz, M.C., Pasmans, F. (2017): Host niche may determine disease-driven extinction risk. PLoS One 12: e0181051.

Bosch, J., Martínez-Solano, I. (2006): Chytrid fungus infection related to unusual mortalities of Salamandra salamandra and Bufo bufo in the Peñalara Natural Park, Spain. Oryx 40: 84-89.

Bosch, J., Sanchez-Tomé, E., Fernández-Loras, A., Oliver, J.A., Fisher, M.C., Garner, T.W.J. (2015): Successful elimination of a lethal wildlife infectious disease in nature. Biol. Lett. 11: 20150874.

Boyle, D.G., Boyle, D.B., Olsen, V., Morgan, J.A., Hyatt, A.D. (2004): Rapid quantitative detection of chytridiomycosis (Batrachochytrium dendrobatidis) in amphibian samples using real-time Taqman PCR assay. Dis. Aquat. Organ. 60 (2): 141-148.

Brooks, T.M., Mittermeier, R.A., da Fonseca, G.A., Gerlach, J., Hoffmann, M., Lamoreux, J.F., Mittermeier, C.G., Pilgrim, J.D., Rodrigues, A.S.L. (2006): Global biodiversity conservation priorities. Science 313: 58-61.

Brown, C.J., Bode, M., Venter, O., Barnes, M.D., McGowan, J., Runge, C.A., Watson, J.E.M., Possingham, H.P. (2015): Effective conservation requires clear objectives and prioritizing actions, not places or species. Proc. Natl. Acad. Sci. U.S.A. 112: e4342.

Brutyn, M., D’Herde, K., Dhaenens, M., Van Rooij, P., Verbrugghe, E., Hyatt, A.D., Croubels, S., Deforce, D., Ducatelle, R., Haesebrouck, F., Martel, A., Pasmans, F. (2012): Batrachochytrium dendrobatidis zoospore secretions rapidly disturb intercellular junctions in frog skin. Fungal Genet. Biol. 49: 830-837.

Buck, J.C., Truong, L., Blaustein, A.R. (2011): Predation by zooplankton on Batrachochytrium dendrobatidis: biological control of the deadly amphibian chytrid fungus? Biodivers. Conserv. 20: 3549-3553.

Buckland, S.T., Studeny, A.C., Magurran, A., Newson, S. (2010): Biodiversity monitoring: the relevance of detectability. In: Biological Diversity: Frontiers in Measurement and Assessment, p. 25-36. Magurran, A.E., McGill, B.J., Eds, Oxford University Press, Oxford.

Canada Gazette Part II (2017, May 31). 151: 11 Retrieved from www.ecology.com/daily_images/

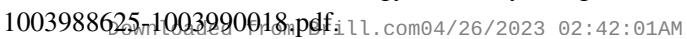


Canessa, S., Converse, S.J., West, M., Clemann, N., Gillespie, G., McFadden, M., Silla, A.J., Parris, K.M., McCarthy, M.A. (2016): Planning for ex-situ conservation in the face of uncertainty. Conserv. Biol. 30: 599-609.

Canessa, S., Bozzuto, C., Grant, E.H.C., Cruickshank, S.S., Fisher, M.C., Koella, J.C., Lötters, S., Martel, A., Pasmans, F., Scheele, B.C., Spitzen-van der Sluijs, A., Steinfartz, S., Schmidt, B.R. (2018): Decision making for mitigating wildlife diseases: from theory to practice for an emerging fungal pathogen of amphibians. J. Appl. Ecol. 55: 1987-1996.

Commission Implementing Decision (EU) 2018/320 of 28 February 2018 on certain animal health protection measures for intra-Union trade in salamanders and the introduction into the Union of such animals in relation to the fungus Batrachochytrium salamandrivorans (notified under document $C$ (2018) 1208) (1) Retrieved from http://eur-lex.europa.eu/eli/dec_impl/2018/320/oj.

Convention on the Conservation of European Wildlife and Natural Habitats (1979): Council of Europe. Retrieved from https://www.coe.int/en/web/ conventions/full-list/-/conventions/treaty/104.

Courtois, E.A., Loyau, A., Bourgoin, M., Schmeller, D.S. (2017): Initiation of Batrachochytrium dendrobatidis infection in the absence of physical contact with infected hosts - a field study in a high altitude lake. Oikos 126: 843-851.

Dalbeck, L., Düssel-Siebert, H., Kerres, A., Kirst, K., Koch, A., Lötters, S., Ohlhoff, D., Sabino-Pinto, J., Preißler, K., Schulte, U., Schulz, V., Steinfartz, S., Veith, M., Vences, M., Wagner, N., Wegge, J. (2018): Die Salamanderpest und ihr Erreger Batrachochytrium salamandrivorans (Bsal): aktueller Stand in Deutschland Zeitschift für Feldherpetologie. 25: 1-22.

Darling, J.A., Mahon, A.R. (2011): From molecules to management: adopting DNA-based methods for monitioring biologcal invasions in aquatic environments. Environmental Research. 111 (7): 978-988.

Denöel, M., Bichot, M., Ficetola, G.F., Delcourt, J., Ylieff, M., Kestemont, P., Poncin, P. (2010): Cumulative effects of road deicing on amphibian behaviour. Aquat. Toxicol. 99: 275-280.

Dickinson, J.L., Shirk, J., Bonter, D., Bonney, R., Crain, R.L., Martin, J., Phillips, T., Purcell, K. (2012): The current state of citizen science as a tool for ecological research and public engagement. Front. Ecol. Environ. 10: 291-297.

Dobson, A. (2004): Population dynamics of pathogens with multiple host species. Am. Nat. 164: s64-s78.

EFSA (European Food Safety Authority), Balàž, V., Schmidt, C.G., Murray, K., Carnesecchi, E., Garcia, A., Gervelmeyer, A., Martino, L., Guajardo, I.M., Verdonck, F., Zancanaro, G., Fabris, C. (2017a): Scientific and technical assistance concerning the establishment, survival and spread of Batrachochytrium salamandrivorans (Bsal) in the EU. EFSA J. 15: 4739.

EFSA (European Food Safety Authority), More, S., Bøtner, A., Butterworth, A., Calistri, P., Depner, K., Edwards, S., Garin-Bastuji, B., Good, M., Schmidt, C.G., Michel, V., Miranda, M.A., Nielsen, S.S., Raj, M., Sihvonen, L., Spoolder, H., Stegeman, J.A., Thulke, H., Velarde, A.,
Willeberg, P., Winckler, C., Baldinelli, F., Broglia, A., Candiani, D., Fabris, C., Georgiadis, M., Zancanaro, G., Beltrán-Beck, B., Kohnle, L., Bicout, D. (2017b): Assessment of listing and categorisation of animal disease within the framework of the Animal Health Law (Regulation (EU) No 2016/429): Batrachochytrium salamandrivorans (Bsal). EFSA J. 15: 5071.

EFSA Panel on Animal Health and Welfare (AHAW), More, S., Miranda, M.A., Bicout, D., Bøtner, A., Butterworth, A., Calistri, P., Depner, K., Edwards, S., Garin-Bastuji, B., Good, M., Michel, V., Raj, M., Nielson, S.S., Sihvonen, L., Spoolder, H., Stegemen, J.A., Thulke, H., Velarde, A., Willeberg, P., Winckler, C., Balàž, V., Martel, A., Murray, K., Fabris, C., Munoz-Gajardo, I., Gogin, A., Verdonck, F., Schmidt, C.G. (2018): Risk of survival establishment, spread of Batrachochytrium salamandrivorans (Bsal) in the EU. EFSA J. 16: 5259.

Farrer, R.A., Martel, A., Verbrugghe, E., Abouelleil, A., Ducatelle, R., Longcore, J.E., James, T.Y., Pasmans, F., Fisher, M.C., Cuomo, C.A. (2017): Genomic innovations linked to infection strategies across emerging pathogenic chytrid fungi. Nat. Commun. 8: 14742.

Feldmeier, S., Schefczyk, L., Wagner, N., Heinemann, G., Veith, M., Lötters, S. (2016): Exploring the distribution of the spreading lethal salamander chytrid fungus in its invasive range in Europe - a macroecological approach. PLoS ONE 11: e0165682.

Ficetola, G.F., Poulenard, J., Sabatier, P., Messager, E., Gielly, L., LeLoup, A., Ettiene, D., Bakke, J., Mallet, E., Fanget, B., Storet, E., Reyys, J., Taberlet, P., Arnaud, F. (2018): DNA from lake sediments reveal patterns of ecosystem changes after a biological invasion. Science Advances 4 (5): eaar486-108292.

Fitzpatrick, L.D., Pasmans, F., Martel, A., Cunningham, A.A. (2018): Epidemiological tracing of Batrachochytrium salamandrivorans identifies widespread infection and associated mortalities in private amphibian collections. Sci. Rep. 8: 13845.

Forrest, M.J., Schlaepfer, M.A. (2011): Nothing a hot bath won't cure: infection rates of amphibian chytrid fungus correlate negatively with water temperature under natural field settings. PLoS ONE 6: e28444.

Freidenburg, L.K., Skelly, D.K. (2004): Microgeographical variation in thermal preference by an amphibian. Ecol. Lett. 7: 369-373.

Gagliardo, R., Crump, P., Griffith, E., Mendelson, J., Ross, H., Zippel, K. (2008): The principles of rapid response for amphibian conservation, using the programmes in Panama as an example. Int. Zoo. Yearb. 42: 125-135.

Game, E.T., Kareiva, P., Possingham, H.P. (2013): Six common mistakes in conservation priority setting. Conserv. Biol. 27: 480-485.

Garmyn, A., van Rooij, P., Pasmans, F., Hellebuyck, T., van den Broeck, W., Haesebrouck, F., Martel, A. (2012): Waterfowl: potential environmental reservoirs of the chytrid fungus Batrachochytrium dendrobatidis. PLoS ONE 7: e35038.

Garner, T.W.J., Schmidt, B.R., Martel, A., Pasmans, F., Muths, E., Cunningham, A.A., Weldon, C., Fisher, M.C., Bosch, J. (2016): Mitigating amphibian chytridiomycoses in nature. Phil. Trans. R. Soc. Lond. B. Biol. Sci. 371: 201602207. aded from Brill.com04/26/2023 02:42:01AM 
Garner, T.W.J., Walker, S., Bosch, J., Hyatt, A.D., Cunningham, A.A., Fisher, M.C. (2005): Chytrid fungus in Europe. Emerging Infect. Dis. 11: 1639-1641.

Geiger, C.C., Bregnard, C., Maluenda, E., Voordouw, M.J., Schmidt, B.R. (2017): Antifungal treatment of wild amphibian populations caused a transient reduction in the prevalence of the fungal pathogen Batrachochytrium dendrobatidis. Sci. Rep. 7: 5956.

Gerber, B.D., Converse, S.J., Muths, E., Crockett, H.J., Mosher, B.A., Bailey, L.L. (2017): Identifying species conservation strategies to reduce disease associated declines. Conserv. Lett. 11 (2): e12393.

Grant, E.H.C., Muths, E., Katz, R.A., Canessa, S., Adams, M.J., Ballard, J.R., Berger, L., Briggs, C.J., Coleman, J., Gray, M.J., Harris, M.C., Harris, R.N., Hossack, B., Huyvaert, K.P., Kolby, J.E., Lips, K.R., Lovich, R.E., McCallum, H.I., Mendelson III, J.R., Nanjappa, P., Olson, D.H., Powers, J.G., Richgels, K.L.D., Russel, R.E., Schmidt, B.R., Spitzen-van der Sluijs, A., Watry, M.K., Woodhams, D.C., White, C.L. (2017): Using decision analysis to support proactive management of emerging infectious wildlife diseases. Front. Ecol. Environ. 15: 214-221.

Grant, E.H.C., Muths, E.L., Katz, R.A., Canessa, S., Adams, M.J., Ballard, J.R., Berger, L., Briggs, C.J., Coleman, J., Gray, M.J., Harris, M.C., Harris, R.N., Hossack, B.R., Huyvaert, K.P., Kolby, J.E., Lips, K.R., Lovich, R.E., McCallum, H.I., Mendelson III, J.R., Nanjappa, P., Olsen, D.H., Powers, J.G., Richgels, K.L.D., Russel, R.E., Schmidt, B.R., Spitzen-van der Sluijs, A., Watry, M.K., Woodhams, D.C., White, C.L. (2015): Salamander chytrid fungus (Batrachochytrium salamandrivorans) in the United States - developig research, monitoring and management strategies: U.S. Geological Survey Open File Report 2015-1233, 16 p. DOI:10.3133/ ofr20151233.

Grogan, L.F., Berger, L., Rose, K., Grillo, V., Cashins, S.D., Skerratt, L.F. (2014): Surveillance for emerging biodiversity diseases of wildlife. PLoS Pathology 10: e1004015.

Guy, R.A., Payment, P., Krull, U.J., Horgen, P.A. (2003): Real-time PCR for quantification of Giardia and Cryptosporidium in environmental water samples and sewage. Appl. Environ. Microbiol. 69: 5178-5185.

Halliday, J.E., Meredith, A.L., Knobel, D.L., Shaw, D.J., de C Bronsvoort, B.M., Cleaveland, S. (2007): A framework for evaluating animals as sentinels for infectious disease surveillance. J. R. Soc. Interface 4: 973-984.

Heard, G.W., Scroggie, M.P., Clemann, N., Ramsey, D.S.L. (2014): Wetland characteristics influence disease risk for a threatened amphibian. Ecol. Appl. 24: 650-662.

Hudson, M.A., Young, R.P., Lopez, J., Martin, L., Fenton, C., McCrea, R., Griffiths, R.A., Adams, S., Gray, G., Garcia, G., Cunningham, A.A. (2016): In-situ itraconazole treatment improves survival rate during an amphibian chytridiomycosis epidemic. Biol. Conserv. 195: $37-45$.

Huver, J.R., Koprivnikar, J., Johnson, P.T.J., Whyard, S. (2015): Development and application of an eDNA method to detect and quantify a pathogenic parasite in aquatic ecosystems. Ecol. Appl. 25: 991-1002.
Isaac, N.J.B., Turvey, S.T., Collen, B., Waterman, C., Baillie, J.E.M. (2007): Mammals on the edge: conservation priorities based on threat and phylogeny. PLoS One 2: e296.

IUCN (2013): Guidelines for Reintroductions and Other Conservation Translocations. IUCN Species Survival Commission. Gland, Switzerland. Retrieved from https://portals.iucn.org/library/efiles/documents/ 2013-009.pdf.

Johnson, M.L., Berger, L., Philips, L., Speare, R. (2003): Fungicidal effects of chemical disinfectants, UV light, desiccation and heat on the amphibian chytrid, Batrachochytrium dendrobatidis. Dis. Aquat. Org. 57: 255260.

Jones, D.K., Mattes, B.M., Hintz, W.D., Schuler, M.S., Stoler, A.B., Lind, L.A., Cooper, R.O., Relyea, R.A. (2016): Investigation of road salts and biotic stressors on freshwater wetland communities. Environ Pollut. 221: 159-167.

Joseph, L.N., Maloney, R.F., Possingham, H.P. (2009): Optimal allocation of resources among threatened species: a project prioritization protocol. Conserv. Biol. 23: 328338.

Karraker, N.E., Gibbs, J.P. (2011): Road deicing salt irreversibly disrupts osmoregulation of salamander egg clutches. Environ. Pollut. 159: 833-835.

Karraker, N.E., Gibbs, J.P., Vonesh, J.R. (2008): Impacts of road deicing salt on the demography of vernal poolbreeding amphibians. Ecol. Appl. 18: 724-734.

Kéry, M., Schmidt, B.R. (2008): Imperfect detection and its consequences for monitoring for conservation. Community Ecol. 9: 207-216.

Klocke, B., Becker, M., Lewis, J., Fleischer, R.C., Muletz, C.R., Rockwood, L., Aguirre, A.A., Gratwicke, B. (2017): Batrachochytrium salamandrivorans not detected in U.S. survey of pet salamanders. Sci. Rep. 7: 13132.

Kolby, J.E., Smith, K.M., Berger, L., Karesh, W.B., Preston, A., Pessier, A.P., Skerratt, L.F. (2014): First evidence of amphibian chytrid fungus (Batrachochytrium dendrobatidis) and ranavirus in Hong Kong amphibian trade. PLoS ONE 9: e90750.

Laking, A.E., Ngo, H.N., Pasmans, F., Martel, A., Nguyen, T.T. (2017): Batrachochytrioum salamandrivorans is the predominant chytrid fungus in Vietnamese salamanders. Sci. Rep. 7: 44443.

Langton, T.E.S., Beckett, C.L., Foster, J.P. (2001): Great Crested Newt Conservation Handbook, Froglife, Halesworth. Retrieved from https://www.abebooks. co.uk/first-edition/Great-Crested-Newt.ConservationHandbook-Tom-Langton.Catherine/7077169734/bd.

Langwig, K.E., Voyles, J., Wilber, M.Q., Frick, W.F., Murray, K.A., Bolker, B.M., Collins, J.P., Cheng, T.L., Fisher, M.C., Hoyt, J.R., Lindner, D.L., McCallum, H.I., Puschendorf, R., Rosenblum, E.B., Toothman, M., Willis, C.K.R., Briggs, C.J., Kilpatrick, A.M. (2015): Context-dependent conservation responses to emerging wildlife diseases. Front. Ecol. Environ. 13: 195-202.

Lawson, B., Petrovan, S.O., Cunningham, A.A. (2015): Citizen science and wildlife disease surveillance. EcoHealth 12; 6937-702.d from Brill.com04/26/2023 02:42:01AM 
Longcore, J.E., Pessier, A.P., Nichols, D.K. (1999): Batrachochytrium dendrobatidis gen. et. sp. nov, a chytrid pathogenic to amphibians. Mycologia 2 (91): 219-227.

Loudon, A.H., Woodhams, D.C., Parfrey, L.W., Archer, H., Knight, R., McKenzie, V., Harris, R.N. (2014): Microbial community dynamics and effect of environmental microbial reservoirs on red-backed salamanders (Plethodon cinereus). ISME J. 8: 830-840.

Loyau, A., Schmeller, D.S. (2017): Positive sentiment and knowledge increase tolerance toward conservation actions. Biodivers. and Conserv. 26: 461-478.

Loyau, A., Cornuau, J.H., Clare, F.C., Schmeller, D.S. (2016): Side effects of itraconazole on postmetamorphic Alytes obstetricans after a cold stress. Amphibian-Reptilia 37: 345-357.

Marquis, O., Miaud, C., Gibault, C., Chai, N. (2019): A first screening of chytrid fungus Batrachochytrium in amphibians in French zoos. Int. Zoo Yearb. 53: 1-10.

Martel, A., Spitzen-van der Sluijs, A., Blooi, M., Bert, W., Ducatelle, R., Fisher, M.C., Woeltjes, A., Bosman, W., Chiers, K., Bossuyt, F., Pasmans, F. (2013): Batrachochytrium salamandrivorans $\mathrm{sp}$. nov. causes lethal chytridiomycosis in amphibians. Proc. Natl. Acad Sci. U.S.A. 110: 15325-15329.

Martel, A., Blooi, M., Adriaensen, C., Van Rooij, P., Beukema, W., Fisher, M.C., Farrer, R.A., Schmidt, B.R., Tobler, U., Goka, K., Lips, K.R., Muletz, C., Zamudio, K.R., Bosch, J., Lötters, S., Wombwell, E., Garner, T.W.J., Cunningham, A.A., Spitzen-van der Sluijs, A., Salvidio, S., Ducatelle, R., Nishikawa, K., Nguyen, T.T., Kolby, J.E., Van Bocxlaer, I., Bossuyt, F., Pasmans, F. (2014): Recent introduction of a chytrid fungus endangers western palearctic salamanders. Science 346: 630631.

Martin, T.G., Nally, S., Burbidge, A.A., Arnall, S., Garnett, S.T., Hayward, M.W., Lumsden, L.F., Menkhorst, P., McDonald-Madden, E., Possingham, H.P. (2012): Acting fast helps avoid extinction. Conserv. Lett. 5: 274280.

McMahon, T.A., Sears, B.F., Venesky, M.D., Bessler, S.M., Brown, J.M., Deutsch, K., Halstead, N.T., Lentz, G., Tenouri, N., Young, S., Civitello, D.J., Ortega, N., Fites, J.S., Reinert, L.K., Rollins-Smith, L.A., Raffel, T.R., Rohr, J.R. (2014): Amphibians acquire resistance to live and dead fungus overcoming fungal immunosuppression. Nature 511: 224-227.

Moilanen, A., Wilson, K.A., Possingham, H., Eds (2009): Spacial Conservation Prioritization: Quantitative Methods and Computational Tools. Oxford University Press, Oxford.

Morán-Ordóñez, A., Canessa, S., Bota, G., Brotons, L., Herrando, S., Hermoso, V. (2018): Efficiency of species survey networks can be improved by integrating different monitoring schemes in a spatial prioritization design. Conserv. Lett. 11: e12591.

Muths, E., McCallum, H. (2016): Why you cannot ignore disease when you reintroduce animals in reintroduction of fish and wildlife populations. In: Reintroduction of Fish and Wildlife Populations. Jachowski, D.S., Millspaugh, J.J., Angermeier, P.L., Slotow, J., Eds, University of California Press, California.
Nguyen, T.T., Nguyen, T.V., Ziegler, T., Pasmans, F., Martel, A. (2017): Trade in wild anurans vectors the urodelan pathogen Batrachohcytrium salamandrivorans into Europe. Amphibia-Reptilia 38: 554-556.

O'Hanlon, S.J., Rieux, A., Farrer, R.A., Rosa, G.M., Waldman, B., Bataille, A., Kosch, T.A., Murray, K.A., Brankovics, B., Fumagalli, M., Martin, M.D., Wales, N., Alvarado-Rybak, M., Bates, K.A., Berger, L., Böll, S., Brookes, L., Clare, F., Courtois, E.A., Cunningham, A.A., Doherty-Bone, T.M., Ghosh, P., Gower, D.J., Hintz, W.E., Höglund, J., Jenkinson, T.S., Lin, C., Laurila, A., Loyau, A., Martel, A., Meurling, S., Miaud, C., Minting, P., Pasmans, F., Schmeller, D.S., Schmidt, B.R., Shelton, J.M.G., Skerrat, L.F., Smith, F., Soto-Azat, C., Spagnoletti, M., Tessa, G., Toledo, L.F., Valenzuela-Sánchez, A., Verster, R., Vörös, J., Webb, R.J., Wierzbicki, C., Wombwell, E., Zamudio, K.R., Aanensen, D.M., James, T.Y., Gilbert, M.T.P., Weldon, C., Bosch, J., Balloux, F., Garner, T.W.J., Fisher, M.C. (2018): Recent Asian origin of chytrid fungi causing global amphibian declines. Science 360: 621-627.

Pasmans, F., Bogaerts, S., Braeckman, J., Cunningham, A.A., Hellebuyck, T., Griffiths, R.A., Sparreboom, M., Schmidt, B.R., Martel, A. (2017): The future of keeping pet reptiles and amphibians: towards integrating animal welfare, human health and environmentall sustainability. Vet. Rec. 181: 450.

Pessier, A.P., Baitchman, E.J., Crump, P., Wilson, B., Griffith, E., Ross, H. (2014): Causes of mortality in anuran amphibians from an ex situ survival assurance colony in Panama. Zoo. Biol. 33: 516-526.

Piotrowski, J.S., Annis, S.L., Longcore, J.E. (2004): Physiology of Batrachochytrium dendrobatidis, a chytrid pathogen of amphibians. Mycologia 96: 9-15.

Pollard, E., Brodie, G., Thaman, R., Morrison, C. (2014): The use of herpetofauna and cultural values to identify priority conservation forests on Malaita, Solomon Islands. Pacific Conserv. Biol. 20: 354-362.

Raffel, T.R., Michel, P.J., Sites, E.W., Rohr, J.R. (2010): What drives chytrid infections in newt populations? Associations with substrate, temperature, and shade. EcoHealth 7: 526-536.

Richgels, K.L.D., Russel, R.E., Adams, M.J., White, C.L., Grant, E.H.C. (2016): Spatial variation in risk and consequence of Batrachochytrium salamandrivorans introduction in the USA. R. Soc. Open Sci. 3: 150616.

Rodríguez-Brenes, S., Rodriguez, D., Ibáñez, R., Ryan, M.J. (2016): Spread of amphibian chytrid fungus across lowland populations of túngara frogs in Panamá. PLoS ONE 11: e 0155745.

Roy, H.E., Rabitsch, W., Scalera, R., Stewart, A., Belinda, G., Genovesi, P., Essl, F., Adriaens, T., Bacher, S., Booy, O., Branquart, E., Brunel, S., Copp, G.H., Dean, H., D'hondt, B., Josefsson, M., Kenis, M., Kettunen, M., Linnamagi, M., Lucy, F., Martinou, A., Moore, N., Nentwig, W., Nieto, A., Pergl, J., Peyton, J., Roques, A., Schindler, S., Schönrogge, K., Solarz, W., Stebbing, P.D., Trichkova, T., Vanderhoeven, S., Van Valkenburg, J., Zenetos, A. (2017): Developing a framework of minimum standards for the risk assessment of alien species. J. Appl. Ecoln 55; $526+538$. Brill. com04/26/2023 02:42: 01AM via free access 
Sabino-Pinto, J., Krause, E.T., Bletz, M.C., Martel, A., Pasmans, F., Steinfartz, S., Vences, M. (2018a): Detectability vs. time and costs in pooled DNA extraction of cutaneous swabs: a study on the amphibian chytrid fungi. Amphibia-Reptilia 39.

Sabino-Pinto, J., Veith, M., Vences, M., Steinfartz, S. (2018b): Asymptomatic infection of the fungal pathogen Batrachochytrium salamandrivorans in captivity. Sci. Rep. 8: 11767.

Savage, A.E., Sredl, M.J., Zamudio, K.R. (2011): Disease dynamics vary spatially and temporally in a North American amphibian. Biol. Conserv. 144: 1910-1915.

Scheele, B.C., Hunter, D.A., Grogan, L.F., Berger, L., Kolby, J., McFadden, M.S., Marantelli, G., Skerratt, L.F., Driscoll, D.A. (2014): Interventions for reducing extinction risk in chytridiomycosis-threatened amphibians. Conserv. Biol. 28: 1195-1205.

Schmeller, D.S., Loyau, A., Bao, K., Brack, W., Chatzinotas, A., De Vleeschower, F., Friesen, J., Gandois, L., Hansson, S.V., Haver, M., Le Roux, G., Shen, J., Teisserenc, R., Vredenburg, V.T. (2018): People pollution and pathogens - global change impacts in mountain freshwater ecosystems. Sci. Total Environ. 622-623: 756-763.

Schmeller, D.S., Blooi, M., Martel, A., Garner, T.W.J., Fisher, M.C., Azemar, F., Clare, F.C., Leclerc, C., Jäger, L., Guevara-Nieto, M., Loyau, A., Pasmans, F. (2014a): Microscopic aquatic predators strongly affect infection dynamics of a globally emerged pathogen. Curr. Biol. 24: 176-180.

Schmeller, D.S., Gruber, B., Budrys, E., Framstead, E., Lengyel, S., Henle, K. (2008): National responsibilities in European species conservation: a methodological review. Conserv. Biol. 22: 593-601.

Schmeller, D.S., Evans, D., Lin, Y.P., Henle, K. (2014b): The national responsibility approach to setting conservation priorities - recommendations for its use. J. Nat. Conserv. 22: 349-357.

Schmidt, B.R., Kéry, M., Ursenbacher, S., Hyman, O.J., Collins, J.P. (2013): Site occupancy models in the analysis of environmental DNA presence/absence surveys: a case study of an emerging amphibian pathogen. Methods in Ecol. Evol. 4: 646-653.

Schmidt, B.R., Bozzuto, C., Lötters, S., Steinfartz, S. (2017): Dynamics of host populations affected by the emerging fungal pathogen Batrachochytrium salamandrivorans. R. Soc. Open Sci. 4: 160801.

Searle, C.L., Mendelson III, J.R., Green, L.E., Duffy, M.A. (2013): Daphnia predation on the amphibian chytrid fungus and its impact on disease risk in tadpoles. Ecol. Evol. 3: 4129-4138.

Skerratt, L.F., Berger, L., Speare, R., Cashins, S., McDonald, K.R., Philpot, A.D., Hines, H.B., Kenyon, N. (2007): Spread of chytridiomycosis has caused the rapid global decline and extinction of frogs. EcoHealth 4: 125.

Spitzen-van der Sluijs, A., Spikmans, F., Bosman, W., de Zeeuw, M., van der Meij, T., Goverse, E., Kik, M., Pasmans, F., Martel, A. (2013): Rapid enigmatic decline drives the fire salamander (Salamandra salamandra) to the edge of extinction in the Netherlands. AmphibiaReptilia 34: 233-239.
Spitzen-van der Sluijs, A., Stegens, G., Bogaerts, S., Canessa, S., Steinfartz, S., Janssen, N., Bosman, W., Pasmans, F., Martel, A. (2018): Post-epizootic salamander persistence in a disease-free refugium suggests poor dispersal ability of Batrachochytrium salamandrivorans. Sci. Rep. 8: 3800.

Spitzen-van der Sluijs, A., Spikmans, F., Bosman, W., de Zeeuw, M., van der Meij, T., Goverse, E., Kik, M., Pasmans, F., Martel, A. (2013): Rapid enigmatic decline drives the fire salamander (Salamandra salamandra) to the edge of extinction in the Netherlands. AmphibiaReptilia 34: 233-239.

Spitzen-van der Sluijs, A., Martel, A., Asselberghs, J., Bales, E.K., Beukema, W., Bletz, M.C., Dalbeck, L., Goverse, E., Kerres, A., Kinet, T., Kirst, K., Laudelout, A., Marin da Fonte, L.F., Nöllert, A., Ohlhoff, D., Sabino-Pinto, J., Schmidt, B.R., Speybroeck, J., Spikmans, F., Steinfartz, S., Veith, M., Vences, M., Wagner, N., Pasmans, F., Lötters, S. (2016): Expanding distribution of lethal amphibian fungus Batrachochytrium salamandrivorans in Europe. Emerging Infect. Dis. 22: 1286-1288.

Stark, T., Martel, A., Pasmans, F., Thomas, V., Gilbert, M., Spitzen, A. (2018): A European early warning system for a deadly salamander pathogen. Amphibian Ark Newsletter 42: 12-14.

Stegen, G., Pasmans, F., Schmidt, B.R., Rouffaer, L.O., Van Praet, S., Schaub, M., Canessa, S., Laudelout, A., Kinet, T., Adriaensen, C., Haesebrouck, F., Bert, W., Bossuyt, F., Martel, A. (2017): Drivers of salamander extirpation mediated by Batrachochytrium salamandrivorans. Nature 544: 353-356.

Stockwell, M.P., Clulow, J., Mahony, M.J. (2012): Sodium chloride inhibits the growth and infective capacity of the amphibian chytrid fungus and increases host survival rates. PLoS One 7: e36942.

Stockwell, M.P., Clulow, J., Mahony, M.J. (2015): Evidence of a salt refuge: chytrid infection loads are suppressed in hosts exposed to salt. Oecologia 177: 901-910.

Taberlet, P., Coissac, E., Hajibabaei, M., Rieseberg, L.H. (2012): Environmental DNA. Mol. Ecol. 21: 1789-1793.

Thomas, V., Blooi, M., Van Rooij, P., Van Praet, S., Verbrugghe, E., Grasselli, E., Lukac, M., Smith, S., Pasmans, F., Martel, A. (2018): Recommendations on diagnostic tools for Batrachochytrium salamandrivorans. Transboundary and Emerging Dis. 65: e478-e488.

Tollefsen, K.E., Song, Y., Kleiven, M., Mahrosh, U., Meland, S., Rosseland, B.O., Teien, H. (2015): Transcriptional changes in Atlantic salmon (Salmo salar) after embryonic exposure to road salt. Aquat. Toxicol. 169: 58-68.

Tulloch, A.I.T., Maloney, R.F., Joseph, L.N., Bennett, J.R., Di Fonzo, M.M., Probert, W.J., O’Connor, S.M., Densem, J.P., Possingham, H.P. (2015): Effect of risk aversion on prioritizing conservation projects. Conserv. Biol. 29: 513-524.

United States Fish and Wildlife Services (2016): Listing Salamanders as Injurious Due to Risk of Salamander Chytrid Fungus. Retrieved from https://www.fws. gov/injurious wildlife/salamanders.btml/26/2023 02:42:01AM 
Van Rooij, P., Martel, A., Haesebrouck, F., Pasmans, F. (2015): Amphibian chytridiomycosis: a review with focus on fungus-host interactions. Vet. Res. 46: 137.

Van Rooij, P., Pasmans, F., Coen, Y., Martel, A. (2017): Efficacy of chemical disinfectants for the containment of the salamander chytrid fungus Batrachochytrium salamandrivorans. PLoS One 12: e0186269.

Voyles, J., Young, S., Berger, L., Campbell, C., Voyles, W.F., Dinudom, A., Cook, D., Webb, R., Alford, R.A., Skerratt, L.F., Speare, R. (2009): Pathogenesis of chytridiomycosis, a cause of catastrophic amphibian declines. Science 326: 582-585.

Walker, S.F., Bosch, J., James, T.Y., Litvintseva, A.P., Oliver Valls, J.A., Piña, S., Garcia, G., Rosa, G.A., Cunningham, A.A., Hole, S., Griffiths, R., Fisher, M.C. (2008): Invasive pathogens threaten species recovery programs. Curr. Biol. 18: R853-R854.

Walker, S.F., Salas, M.B., Jenkins, D., Garner, T.W.J., Cunningham, A.A., Hyatt, A.D., Bosch, J., Fisher, M.C. (2007): Environmental detection of Batrachochytrium dendrobatidis in a temperate climate. Dis. Aquat. Organ. 77: 105-112.

Wild Animal and Plant Protection and Regulation of International and Interprovincial trade Act (2017): Retrieved from https://www.canlii.org/en/ca/laws/regu/ sor-96-263/latest/sor-96-263.html.

Woodhams, D.C., Bosch, J., Briggs, C.J., Cashins, S., Davis, L.R., Lauer, A., Muths, E., Puschendorf, R., Schmidt, B.R., Sheafor, B., Voyles, J. (2011): Mitigating amphibian disease: strategies to maintain wild populations and control chytridiomycosis. Front. Zool. 8: 8.

Yuan, Z., Martel, A., Wu, J., Van Praet, S., Canessa, S., Frank Pasmans, F. (2018): Widespread occurence of an emerging fungal pathogen in heavily traded Chinese urodelan species. Conserv. Lett.: e12436.

Submitted: November 13, 2018. Final revision received: July 3, 2019. Accepted: July 3, 2019.

Associate Editor: Judit Vörös. 